\title{
Epigenetic reprogramming by TET enzymes impacts co-transcriptional R-loops
}

Affiliations: ${ }^{1}$ Instituto de Medicina Molecular João Lobo Antunes, Faculdade de Medicina da Universidade de Lisboa, Lisboa, Portugal.

*Correspondence to: sergioalmeida@medicina.ulisboa.pt

tCurrent address: UCIBIO-REQUIMTE, Departamento de Ciências da Vida, Faculdade de Ciências e Tecnologia, Universidade NOVA de Lisboa, 2829-516 Caparica, Portugal

\section{Abstract}

DNA oxidation by ten-eleven translocation (TET) family enzymes is essential for epigenetic reprogramming. The conversion of 5-methylcytosine $(5 \mathrm{mC})$ into 5-hydroxymethylcytosine (5hmC) initiates developmental and cell-type-specific transcriptional programs through mechanisms that include changes in the chromatin structure. Here, we show that the presence of $5 \mathrm{hmC}$ in the transcribed DNA promotes the annealing of the nascent RNA to its template DNA strand, leading to the formation of an R-loop. The genome-wide distribution of $5 \mathrm{hmC}$ and R-loops show a positive correlation in mouse and human embryonic stem cells and overlap in half of all active genes. Moreover, R-loop resolution leads to differential expression of a subset of genes that are involved in crucial events during stem cell proliferation. Altogether, our data reveal that epigenetic reprogramming via TET activity promotes co-transcriptional R-loop formation, and disclose novel links between R-loops and the regulation of gene expression programs in stem cells. 
bioRxiv preprint doi: https://doi.org/10.1101/2021.04 26.441414 this version posted April 27, 2021. The copyright holder for this preprint (which was not certified by peer review) is the author/funder, who has granted bioRxiv a license to display the preprint in perpetuity. It is made available under aCC-BY 4.0 International license.

INTRODUCTION

During transcription, the nascent RNA molecule can hybridize with the template DNA and form a DNA:RNA hybrid and a displaced DNA strand. These triple-stranded structures, called R-loops, are physiologically relevant intermediates of several processes, such as immunoglobulin class-switch recombination and gene expression ${ }^{1}$. However, non-scheduled or persistent R-loops constitute an important source of DNA damage, namely DNA doublestrand breaks (DSBs) ${ }^{1}$. To preserve genome integrity, cells possess diverse mechanisms to prevent the formation of R-loops or resolve them. R-loop formation is restricted by RNAbinding proteins and topoisomerase 1 , whereas R-loops are removed by ribonucleases and helicases (reviewed $\mathrm{in}^{1}$ ). The ribonuclease $\mathrm{H}$ enzymes RNase $\mathrm{H} 1$ and RNase $\mathrm{H} 2$ degrade Rloops by digesting the RNA strand of the DNA:RNA hybrid. DNA and RNA helicases unwind the hybrid and restore the double-stranded DNA (dsDNA) structure. Several helicases unwind R-loops at different stages of the transcription cycle and in distinct physiological contexts $^{1}$. For instance, we previously reported that the DEAD-box helicase 23 (DDX23) resolves R-loops formed during transcription elongation to regulate gene expression programs and prevent transcription-dependent DNA damage ${ }^{2}$. Intrinsic features of the transcribed DNA also influence its propensity to form R-loops. The presence of introns, for instance, prevents unscheduled R-loop formation at active genes ${ }^{3}$. An asymmetrical distribution of guanines (G) and cytosines (C) nucleotides in the DNA duplex also influences R-loop propensity, with an excess of $\mathrm{Cs}$ in the template DNA strand (positive G:C skew) favouring R-loop formation ${ }^{4}$. Moreover, chromatin and DNA features such as histone modifications, DNA-supercoiling and G-quadruplex structures also affect R-loop establishment ${ }^{1}$. R-loops can also drive chromatin modifications. Promoter-proximal R-loops enhance the recruitment of the Tip60-p400 histone acetyltransferase complex and inhibit the binding of polycomb repressive complex 2 and histone $\mathrm{H} 3$ lysine-27 methylation ${ }^{5}$. Rloops formed over G-rich terminator elements promote histone H3 lysine-9 dimethylation, a repressive mark that reinforces RNA polymerase II pausing during transcription termination ${ }^{6-8}$.

Besides affecting histone modifications, R-loops also act as barriers against DNA 61 methylation spreading into active genes ${ }^{4,9}$. DNA methylation, namely 5-methylcytosine $62(5 \mathrm{mC})$, results from the covalent addition of a methyl group to the carbon 5 of a $C$ attached 63 to a $G$ through a phosphodiester bond $(\mathrm{CpG})^{10}$. The activity of DNA methyltransferase 
bioRxiv preprint doi: https://doi.org/10.1101/2021.04 26 441414 this version posted April 27, 2021. The copyright holder for this preprint (which was not certified by peer review) is the author/funder, who has granted bioRxiv a license to display the preprint in perpetuity. It is made available under aCC-BY 4.0 International license.

(DNMT) enzymes makes $5 \mathrm{mC}$ widespread across the mammalian genome where it plays major roles in imprinting, suppression of retrotransposon silencing and gene expression ${ }^{11}$. More than $70 \%$ of all human gene promoters contain stretches of CpG dinucleotides, termed CpG islands (CGIs), whose transcriptional activity is repressed by CpG methylation ${ }^{11,12}$. R-loops positioned near the promoters of active genes maintain CGIs in an unmethylated state ${ }^{9}$, likely by reducing the affinity of DNMT1 binding to DNA ${ }^{13}$, or recruiting methylcytosine dioxygenases ten-eleven translocation (TET) enzymes ${ }^{14}$.

The TET enzymes family members share the ability to oxidize $5 \mathrm{mC}$ to 5 hydroxymethylcytosine $(5 \mathrm{hmC})^{15,16} .5 \mathrm{hmC}$ is a relatively rare DNA modification found across the genome much less frequently than $5 \mathrm{mC}^{17}$. Genome-wide, $5 \mathrm{hmC}$ is more abundant at regulatory regions near transcription start sites (TSSs), promoters and exons, consistent with its role in gene expression regulation ${ }^{18}$. The levels of $5 \mathrm{hmC}$ are enriched at active promoter regions, as observed upon activation of neuronal function-related genes in neural progenitors and neurons ${ }^{15,19}$. $5 \mathrm{hmC}$ has the potential to modify the DNA helix structure by favouring DNA-end breathing motion, a dynamic feature of the protein-DNA complexes thought to control DNA accessibility ${ }^{17}$. Moreover, $5 \mathrm{hmC}$ weakens the interaction between DNA and nucleosomal $\mathrm{H} 2 \mathrm{~A}-\mathrm{H} 2 \mathrm{~B}$ dimers, facilitating RNA polymerase II elongation, and diminishes the thermodynamic stability of the DNA duplex ${ }^{17}$. While $5 \mathrm{mC}$ increases the melting temperature, $5 \mathrm{hmC}$ reduces the amount of energy needed to separate the two strands of the DNA duplex ${ }^{20,21}$. Molecular dynamics simulations revealed that the highest amplitude of GC DNA base-pair fluctuations is observed in the presence of $5 \mathrm{hmC}$, whereas $5 \mathrm{mC}$ yielded GC base pairs with the lower amplitude values ${ }^{21}$. The presence of $5 \mathrm{hmC}$ destabilizes GC pairing by alleviating steric constraints through an increase in molecular polarity ${ }^{21}$.

Because features that destabilize the DNA duplex, such as supercoiling or Gquadruplexes, are known to facilitate nascent RNA annealing with the template DNA strand, we reasoned that $5 \mathrm{hmC}$ may favour R-loop formation. Here, we show that $5 \mathrm{hmC}$ promotes R-loop formation during in vitro transcription of DNA templates. Moreover, changing the expression levels and genomic targeting of TET enzymes affects R-loop levels in cells. Analysis of genome-wide distribution profiles shows a positive correlation between $5 \mathrm{hmC}$ and R-loops in mouse embryonic stem (mES) and human embryonic kidney 293 (HEK293) cells, with a clear overlap of $5 \mathrm{hmC}$ and R-loops in approximately half of all active genes. We 
bioRxiv preprint doi: https://doi.org/10 1101/2021.04 26.441414 this version posted April 27, 2021. The copyright holder for this preprint (which was not certified by peer review) is the author/funder, who has granted bioRxiv a license to display the preprint in perpetuity. It is made available under aCC-BY 4.0 International license.

also show that $5 \mathrm{hmC}$-rich regions are characterized by increased levels of phosphorylated histone $\mathrm{H} 2 \mathrm{AX}(\gamma \mathrm{H} 2 \mathrm{AX})$, a marker of DNA damage. Finally, by determining the pathways more significantly affected by $\mathrm{R}$-loops formed at $5 \mathrm{hmC}$ loci, we propose a novel function for $\mathrm{R}$ loops in regulating gene expression programs that drive stem cell proliferation.

\section{RESULTS}

\section{Transcription through 5hmC-rich DNA favours R-loop formation}

To assess the impact of cytosine methylation on R-loop formation, we performed in vitro T7 transcription of DNA fragments containing either native or modified cytosine deoxyribonucleotides (dCTPs). We synthesized three distinct DNA transcription templates, each composed of a T7 promoter followed by a 400bp sequence containing a genomic region prone to form R-loops in vivo ${ }^{2,8}$. Two of these sequences (B-actin P1 and B-actin P2) are from the transcription termination region of the 8 -actin gene; the third sequence is from the APOE gene. The DNA templates for the in vitro transcription reactions were generated by PCR-amplification in the presence of dNTPs containing either native $\mathrm{C}, 5 \mathrm{mC}$, or $5 \mathrm{hmC}$ (Figure 1A). Successful incorporation of dCTP variants was confirmed by immunoblotting using specific antibodies against each variant (Figure 1B). The formation of R-loops during the in vitro transcription reactions was inspected by blotting immobilized RNAs with the S9.6 antibody, which recognizes the DNA:RNA hybrids (Figure 1C). To increase the specificity of hybrid detection, all samples were treated with RNase A in high salt conditions in order to digest all RNA molecules except those engaged in R-loops. The specific detection of DNA:RNA hybrids was confirmed by blotting transcription reaction products previously digested with RNase $\mathrm{H}$ (Figure $1 \mathrm{C}$ ). In agreement with our hypothesis that $5 \mathrm{hmC}$ favours Rloops, increased amounts of DNA:RNA hybrids were detected in samples derived from in vitro transcription of 5hmC-rich 8 -actin $\mathrm{P} 1,8$-actin $\mathrm{P} 2$ and APOE DNA templates (Figure 1D). To directly visualize and quantify R-loop structures obtained in the in vitro transcription reactions we performed atomic force microscopy (AFM) experiments (Figure 1E). R-loops were visualized as blob, spur or loop structures, as previously described ${ }^{22,23}$. Quantification of these structures revealed that transcription products from 5hmC-rich DNA templates were enriched in R-loops, which were extensively lost upon RNase $\mathrm{H}$ treatment. 
bioRxiv preprint doi: https://doi.org/10.1101/2021.04.26.441414; this version posted April 27, 2021. The copyright holder for this preprint (which was not certified by peer review) is the author/funder, who has granted bioRxiv a license to display the preprint in perpetuity. It is made available under aCC-BY 4.0 International license.

A

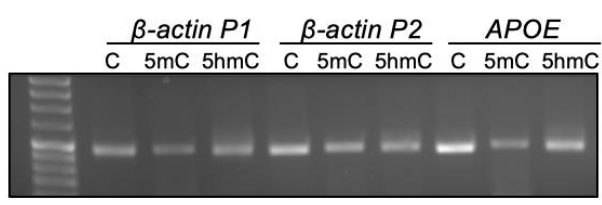

B

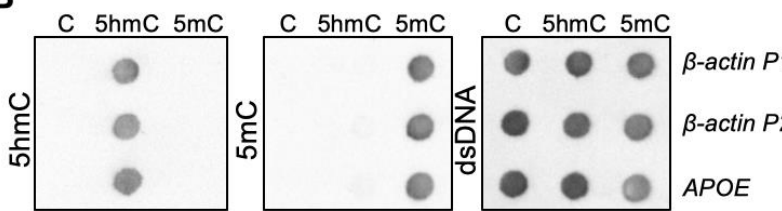

C

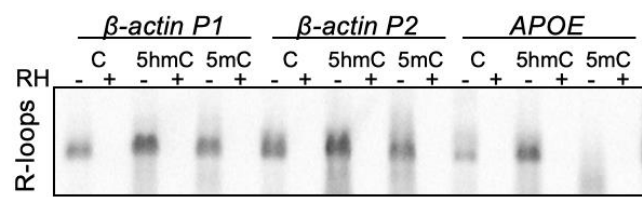

D

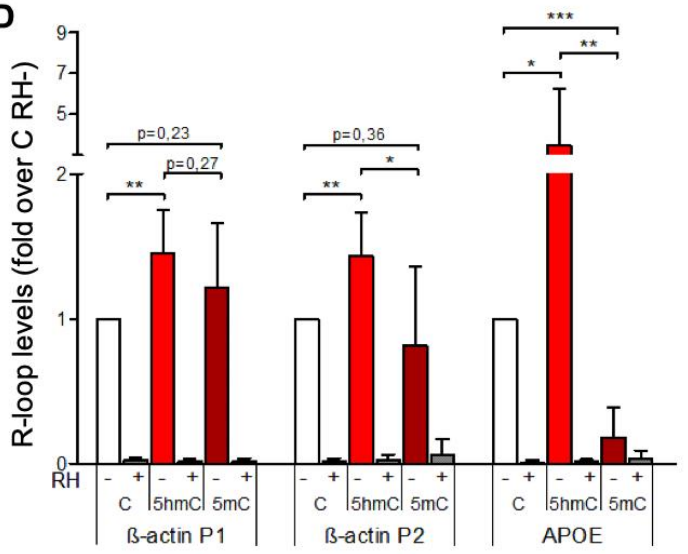

E
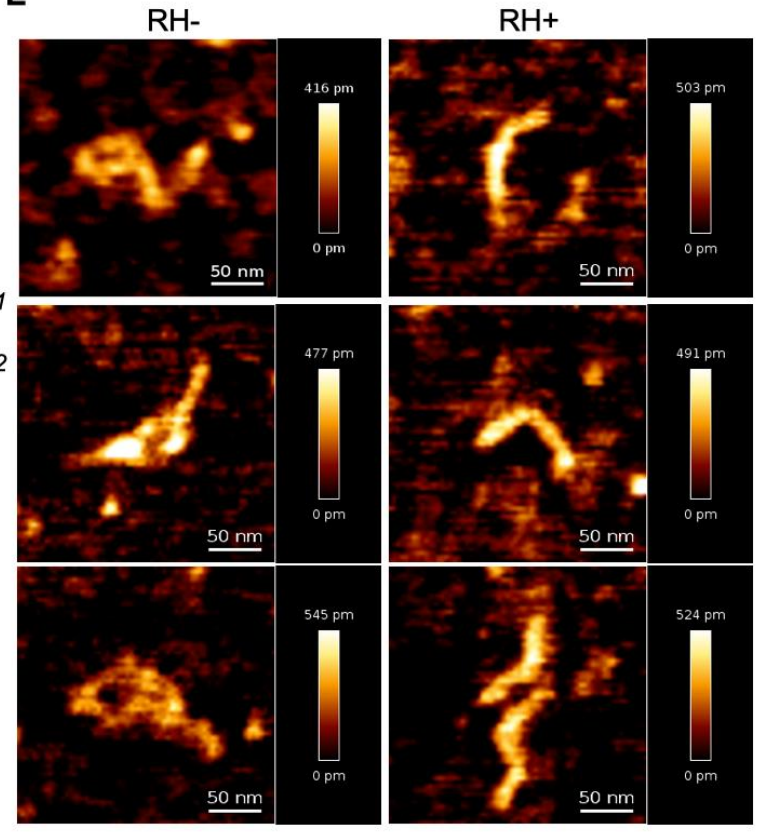

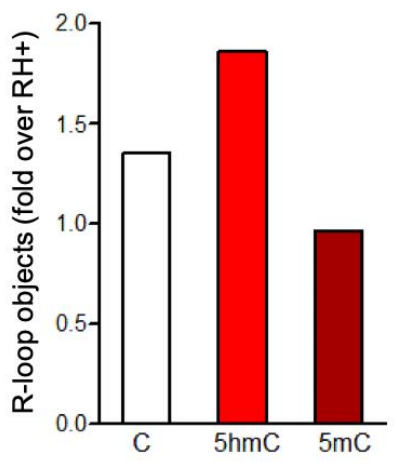

127 Figure1: $\mathbf{5 h m C}$ favours co-transcriptional R-loop formation. (A) Native or modified dCTPs were 128 incorporated upon PCR amplification into DNA fragments with sequences from the transcription 129 termination region of the $\beta$-actin gene ( $\beta$-actin $\mathrm{P} 1$ and $\beta$-actin $\mathrm{P} 2$ ) or the APOE gene. (B) 130 Incorporation of dCTP variants confirmed by immunoblotting using specific antibodies against $5 \mathrm{mC}$, $1315 \mathrm{hmC}$ and double-stranded DNA (dsDNA). (C) R-loops formed upon in vitro transcription reactions 132 were detected by immunoblotting using the $\$ 9.6$ antibody. RNase H-treated in vitro transcription reaction products $(\mathrm{RH}+)$ serve as negative controls. All data are representative of seven independent experiments with similar results. (D) S9.6 immunoblots were quantified and the R-loop levels normalized against the levels detected in the reaction products of DNA templates containing native C. Data represent the mean and standard deviation (SD) from seven independent experiments. ${ }^{*} p<0.05,{ }^{* *} p<0.01$ and ${ }^{* * *} p<0.001$, using two-tailed Student's $t$ test. (E) In vitro transcription reaction products of $\beta$-actin $\mathrm{P} 2$ templates were visualized using atomic force microscopy. R-loop structures obtained from $5 \mathrm{hmC}$-containing $\beta$-actin $\mathrm{P} 2$ transcription in the absence $(\mathrm{RH}-)$ or presence $(\mathrm{RH}+)$ of $\mathrm{RNase} \mathrm{H}$ are shown. R-loops present in the transcription reaction products of $\mathrm{C}, 5 \mathrm{mC}$ or $5 \mathrm{hmC}$-containing $\beta$-actin $\mathrm{P} 2$ templates were counted in a minimum of 80 filaments observed in three individual AFM experiments. 
bioRxiv preprint doi: https://doi.org/10 1101/2021.04 26.441414 - this version posted April 27, 2021. The copyright holder for this preprint (which was not certified by peer review) is the author/funder, who has granted bioRxiv a license to display the preprint in perpetuity. It is made available under aCC-BY 4.0 International license.

\section{TET enzymatic activity impacts endogenous R-loop levels}

146 We next sought to test whether the 5hmC DNA modification induces R-loop formation in

147 cells. We quantified R-loop levels in mES cells carrying doxycycline (dox)-inducible shRNAs

148 targeting either Tet1 or $\operatorname{Tet}^{24}$ (Figure 2A). In agreement with their role in converting $5 \mathrm{mC}$

149 into $5 \mathrm{hmC}$, knockdown of Tet1 and Tet3 in mES cells resulted in decreased total cellular

$1505 \mathrm{hmC}$, whereas $5 \mathrm{mC}$ showed a mild increase (Figure 2B). Dot-blot hybridization of total

151 cellular nucleic acids using the $\$ 9.6$ antibody revealed that depletion of each TET enzyme

152 reduced endogenous R-loops (Figure $\mathbf{2 C}$ ). We then asked whether global changes in

153 transcription rates contributed to reducing R-loop levels in TET1-depleted cells. We

154 quantified fluorescent 5-ethynyl uridine (EU) incorporation into nascent RNA molecules in mES cells upon TET1 knockdown (Figure 2D). TET1 knockdown did not reduce global EU incorporation, indicating that diminished transcription cannot account for the observed reduction in R-loop levels.

Next, we employed a modified CRISPR-based system to target TET enzymatic activity to specific loci ${ }^{25}$. We used a pool of three specific guide RNAs (gRNAs) to direct a

160 catalytically inactive Cas9 nuclease fused to the catalytic domain of TET1 (dCas9-TET1) to

161 the last exon of the $A P O E$ gene. As a control, dCas9 was fused to an inactive mutant version

162 of the TET1 catalytic domain (dCas9-dTET1). Local enrichment of 5hmC following dCas9-

163 TET1 targeting at the APOE locus was confirmed by DNA immunoprecipitation using

164 antibodies specific for $5 \mathrm{mC}$ or $5 \mathrm{hmC}$ modified nucleotides (Figures 2E). DNA:RNA

165 immunoprecipitation (DRIP) experiments detected increased R-loop levels in the last exon

166 of APOE upon tethering of dCas9-TET1 but not of dCas9-dTET1 (Figures 2F). Collectively,

167 these data suggest that editing $5 \mathrm{hmC}$ density by changing the expression levels or the

168 genomic distribution of TET enzymes influences R-loop formation in cells. 
A

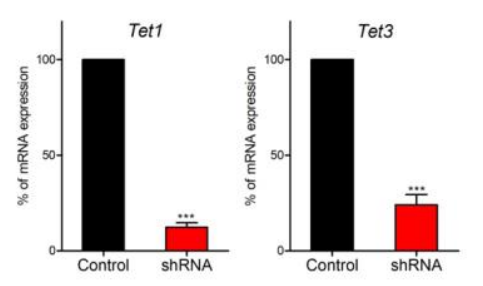

C
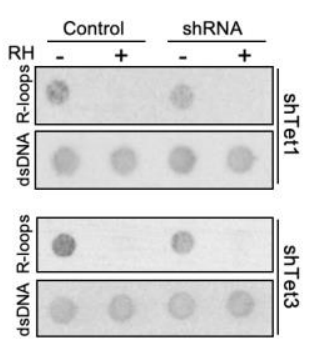

D

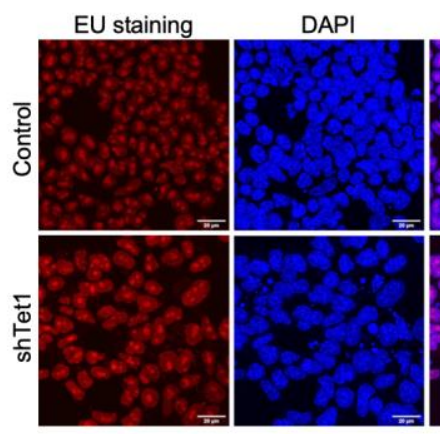

E

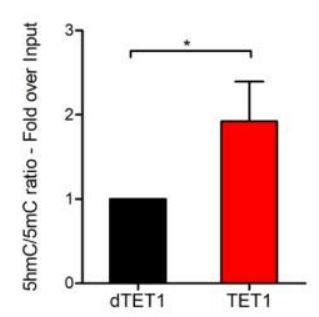

B
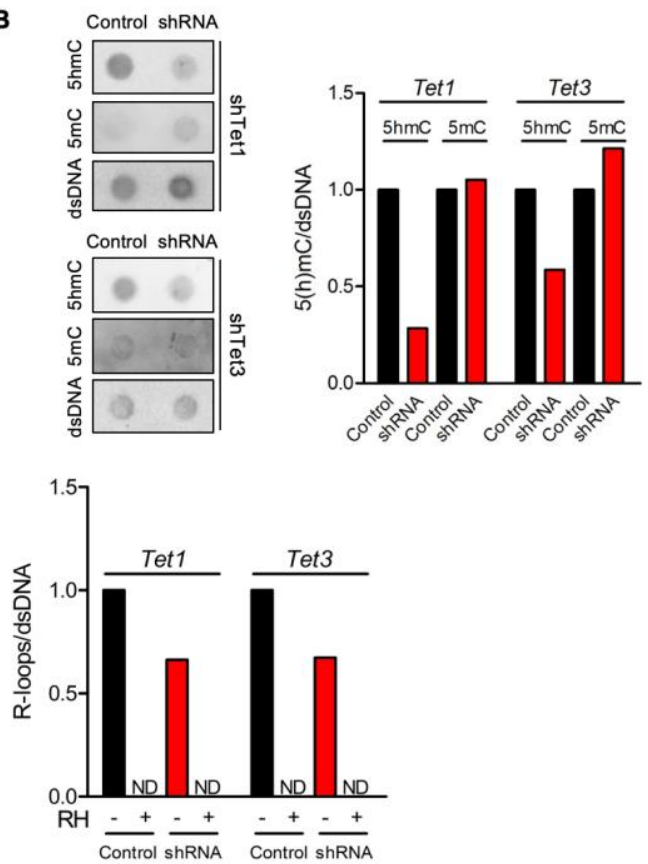

$\mathbf{F}$
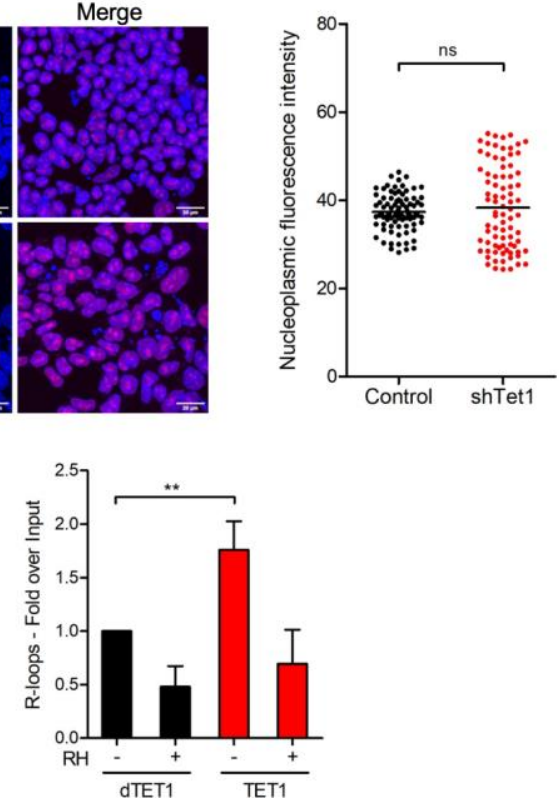

171 Figure 2: TET enzymatic activity impacts R-loop levels. (A) Tet1 and Tet3 mRNA expression levels in mES cells stably expressing dox-inducible shRNA targeting Tet1 or Tet3. Graphs show mean and SD of mRNA expression in dox-treated cells normalized to control cells (no dox). Data are from three independent experiments. ${ }^{* *} \mathrm{p}<0.001$, two-tailed Student's $\mathrm{t}$ test. (B) $5 \mathrm{mC}$ and $5 \mathrm{hmC}$ immunoblot in Tet1 and Tet3-depleted cell extracts (shTet1 and shTet3). Blots were quantified, normalized against dsDNA levels and plotted in a bar graph. Data are representative of three independent experiments. (C) R-loops were detected by immunoblot in Tet1 and Tet3-depleted cell extracts. Blots were quantified, normalized against dsDNA levels and plotted in a bar graph. Data are representative of three independent experiments. ND=not detected. (D) Transcription levels in Tet1depleted mES cells assessed through EU-incorporation. DAPI was added to stain DNA. Scale bars: 20 $\mu \mathrm{m}$. Data are representative of three independent experiments with similar results. The scatter plot represents EU nucleoplasmic fluorescence intensity. Horizontal solid lines represent the mean 
183 values. Over 90 cells from three individual experiments were scored for each experimental condition

184 and statistical significance was determined using the Mann Whitney test ( $p>0.05)$. (E) Changes in the

$1855 \mathrm{hmC} / 5 \mathrm{mC}$ ratio at the last exon of the APOE gene in U2OS cells expressing dCas9-TET1 or dCas9-

186 dTET1 with gRNA targeting this locus. Data show the mean and SD of the $5 \mathrm{hmC} / 5 \mathrm{mC}$ ratio obtained

187 in cells expressing dCas9-TET1 normalized to the same ratio in dCas9-dTET1 cells from three

188 independent experiments. ${ }^{*} p<0.05$, two-tailed Student's $t$ test. (F) R-loop levels in the APOE locus

189 assessed by DRIP. Data show R-loop levels in dCas9-TET1 expressing cells normalized to dCas9-dTET1

190 cells. RNase $\mathrm{H}$-treated samples $(\mathrm{RH}+)$ serve as negative controls. Mean and SD are from three

191 independent DRIP experiments. ${ }^{*} p<0.01$, two-tailed Student's $t$ test.

$5 \mathrm{hmC}$ and $\mathrm{R}$-loops overlap genome-wide at transcriptionally active genes

194 To further inspect the link between $5 \mathrm{hmC}$ and R-loops we performed computational 195 analyses of 5hmC antibody-based DNA immunoprecipitation (hMeDIP-seq) and DNA:RNA immunoprecipitation (DRIP-seq) datasets from mES and HEK293 cells ${ }^{5,26-28}$. To assess

197 individual genome-wide distribution profiles, R-loops density was probed over fixed

198 windows of $\pm 10 \mathrm{kbp}$ around the $5 \mathrm{hmC}$ peaks (Figure $3 \mathbf{A}$ and Supplementary Figure $1 \mathrm{~A})$. The resulting metagene plots and heatmaps revealed a marked overlap between $5 \mathrm{hmC}$-rich loci and R-loops. Despite the distinct distribution patterns of $5 \mathrm{hmC}$ (well-defined peaks) and Rloops (reads spanning genomic regions with highly heterogeneous lengths, ranging between a few dozen to over $1 \mathrm{~kb}^{5}$, we could obtain a statistically significant Pearson correlation coefficient between both $(p<0.05)$ (Figure 3B and Supplementary Figure 1B). Furthermore, approximately half of all R-loops detected genome-wide occurred at 5hmC-containing loci (Figure 3C and Supplementary Figure 1C). Notably, we observed an overlap between $5 \mathrm{hmC}$ and R-loops in 6839 (51\%) out of the 13288 actively expressed genes (Figure 3D), a feature illustrated in the individual profiles of mouse and human genes (Figure $3 \mathrm{E}$ and

208 Supplementary Figure 1D). Metagene profiles revealed very similar patterns of intragenic 209 distribution, with both $5 \mathrm{hmC}$ and R-loops increasing towards the transcription termination 210 site (TTS), where they reached maximum levels (Figure 3F). At the transcription start sites 211 (TSS), however, the 5hmC DNA modification was mostly absent, whereas R-loops were 212 abundant. The detection of R-loop peaks at TSS regions is in agreement with previous 213 studies $^{4,9}$ and imply that $5 \mathrm{hmC}$ is not necessary for co-transcriptional DNA:RNA 214 hybridization and R-loop formation. 


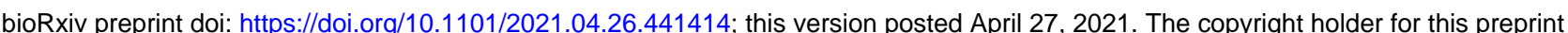
(which was not certified by peer review) is the author/funder, who has granted bioRxiv a license to display the preprint in perpetuity. It is made available under aCC-BY 4.0 International license.

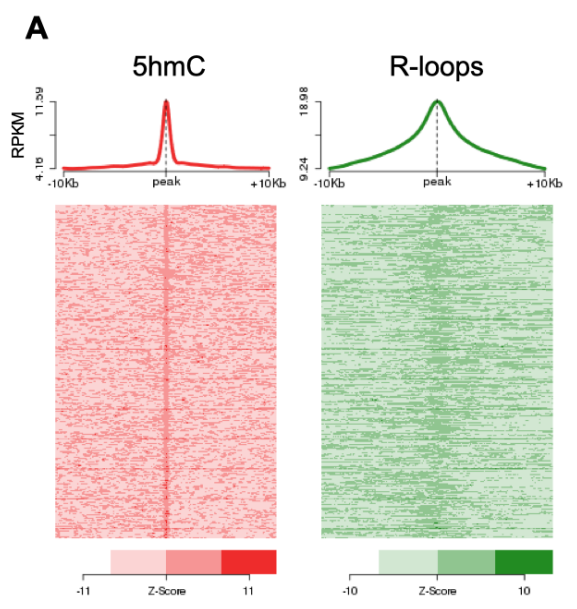

B

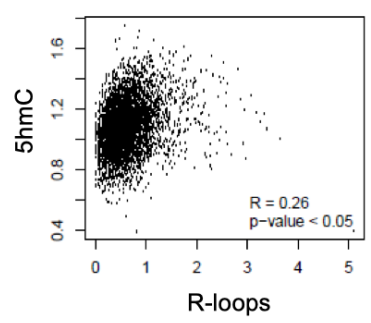

D

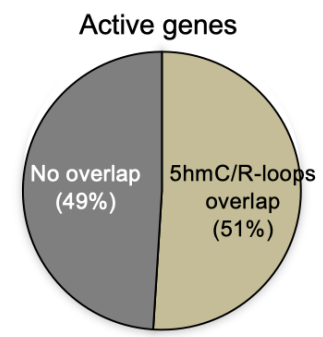

E

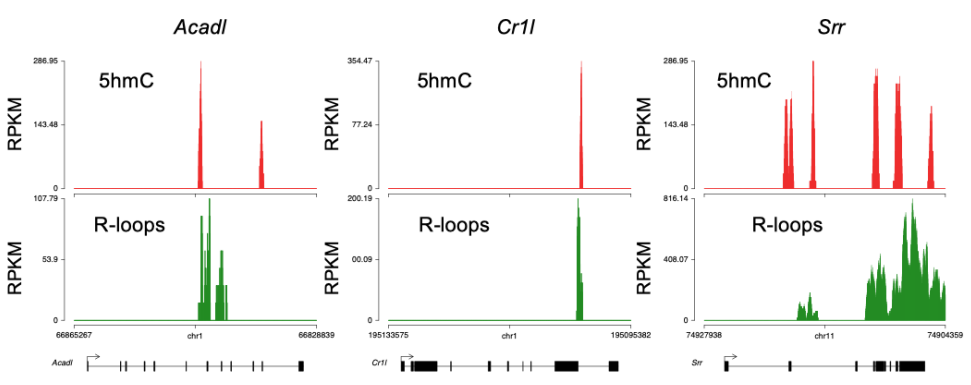

C
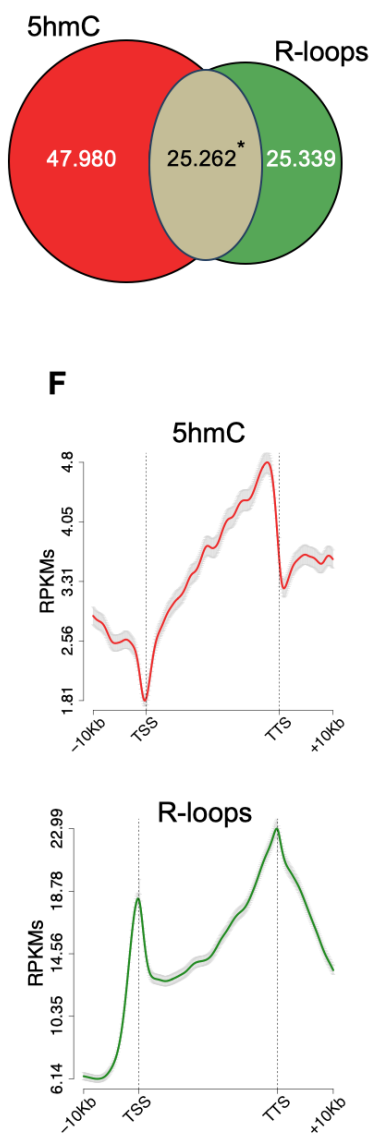

Figure 3: $5 \mathrm{hmC}$ and R-loops overlap in active genes of $\mathrm{mES}$ cells. (A) Metagene and heatmap profiles of $5 \mathrm{hmC}$ and R-loops probed over fixed windows of $\pm 10 \mathrm{kbp}$ around the $5 \mathrm{hmC}$ peaks in expressed genes. (B) Pearson correlation coefficient between $5 \mathrm{hmC}$ and R-loops distribution within active genes $(p<0.05)$. (C) Number of loci displaying $5 \mathrm{hmC}, \mathrm{R}$-loops, and overlapping $5 \mathrm{hmC}$ and Rloops. *Permutation analysis, $p<0.05$. (D) Percentage of active genes displaying overlapping $5 \mathrm{hmC}$ and R-loops. (E) Individual profiles of $5 \mathrm{hmC}$ and R-loop distribution along the Acadl, $\mathrm{Cr} 1 \mathrm{l}$ and $\mathrm{Srr}$ genes. Density signals are represented as reads per kilobase (RPKMs). (F) Metagene profiles of $5 \mathrm{hmC}$ and R-loops distribution in active genes. The gene body region was scaled to 60 equally-sized bins and $\pm 10 \mathrm{kbp}$ gene-flanking regions were averaged in $200 \mathrm{bp}$ windows. TSS: transcription start site. TTS: transcription termination site. Density signals are represented as RPKMs and error bars (gray) represent standard error of the mean.

We then sought to simultaneously detect $5 \mathrm{hmC}$ and $\mathrm{R}$-loops at the same loci in individual mES cells. We performed proximity ligation assays (PLA) using $\mathrm{S9.6}$ and anti-5hmC antibodies (Figure 4A). While control reactions with each antibody alone or without primary antibodies did not produce a significant PLA signal, staining with 59.6 and anti-5hmC antibodies gave rise to a robust signal scattered throughout the nucleus in $92 \%$ of all cells 
A

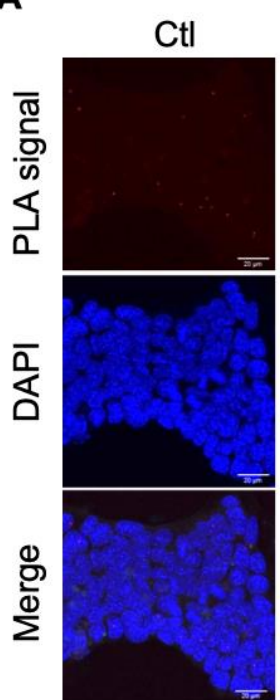

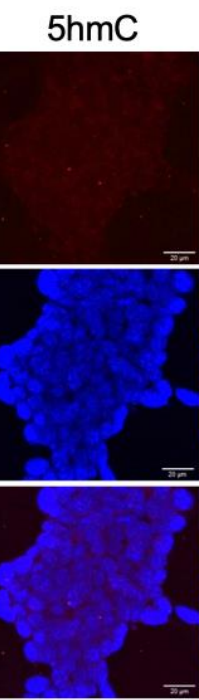

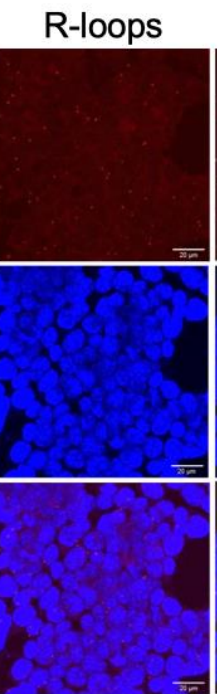

$5 \mathrm{hmC}$

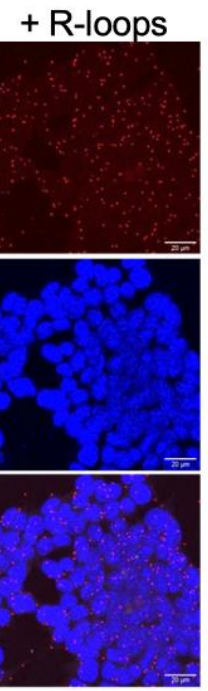

B

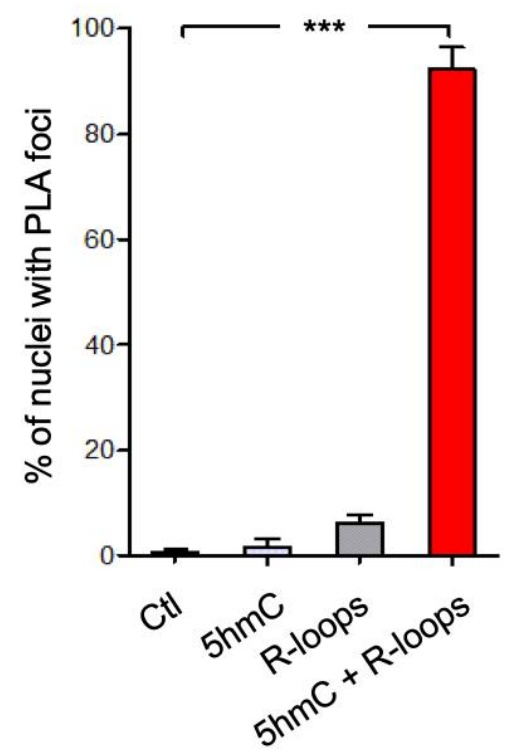

Figure 4: Simultaneous detection of $5 \mathrm{hmC}$ and $\mathrm{R}$-loops at the same genomic loci in individual $\mathrm{mES}$ cells. (A) $5 \mathrm{hmC}$ and R-loops PLA foci in mES cells. DAPI was added to the mounting medium to stain DNA. Scale bars: $20 \mu \mathrm{m}$. Data are representative of three independent experiments with similar results. (B) The bar graph shows the mean and SD of the percentage of cells containing $5 \mathrm{hmC}$ and Rloops PLA foci. A minimum of 300 cells from three individual experiments was scored for each experimental condition. ${ }^{* *} p<0.001$, two-tailed Student's $t$ test.

\section{5hmC-rich loci are genomic hotspots for DNA damage}

243 Disruption of R-loop homeostasis is a well-described source of genomic instability ${ }^{1}$. For 244 instance, co-transcriptional R-loops increase conflicts between transcription and replication 245 machineries by creating an additional barrier to fork progression ${ }^{29,30}$. Such conflicts may 246 cause DNA damage, including DSBs, which can be revealed using antibodies against $\gamma \mathrm{H} 2 \mathrm{AX}$.

247 We analysed the genomic distribution of $\gamma \mathrm{H} 2 \mathrm{AX}$ by interrogating chromatin 248 immunoprecipitation followed by sequencing (ChIP-seq) data from HEK293 cells ${ }^{31}$. The 249 individual distribution profiles of $\gamma \mathrm{H} 2 \mathrm{AX}$ were analysed over fixed windows of $\pm 10 \mathrm{kbp}$ 250 around the $5 \mathrm{hmC}$ peaks detected in the same cells (Figure $\mathbf{5 A}$ ). The resulting metagene plots 251 revealed marked enrichment of $\gamma \mathrm{H} 2 \mathrm{AX}$ at $5 \mathrm{hmC}$-rich loci. The genic distribution of $5 \mathrm{hmC}$ and 252 R-loops along three different genes further showed co-localization of the two marks with $253 \gamma \mathrm{H} 2 \mathrm{AX}$ (Figure 5B). Analysis of $\gamma \mathrm{H} 2 \mathrm{AX}$ and $5 \mathrm{hmC}$ distribution within active genes revealed a low yet statistically significant Pearson correlation coefficient $(p<0.05)$ (Figure 5 C). 
A

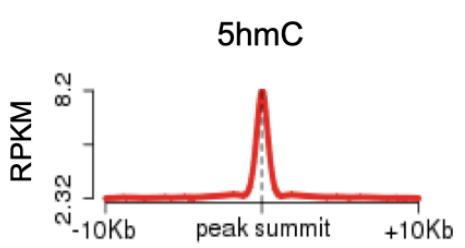

B
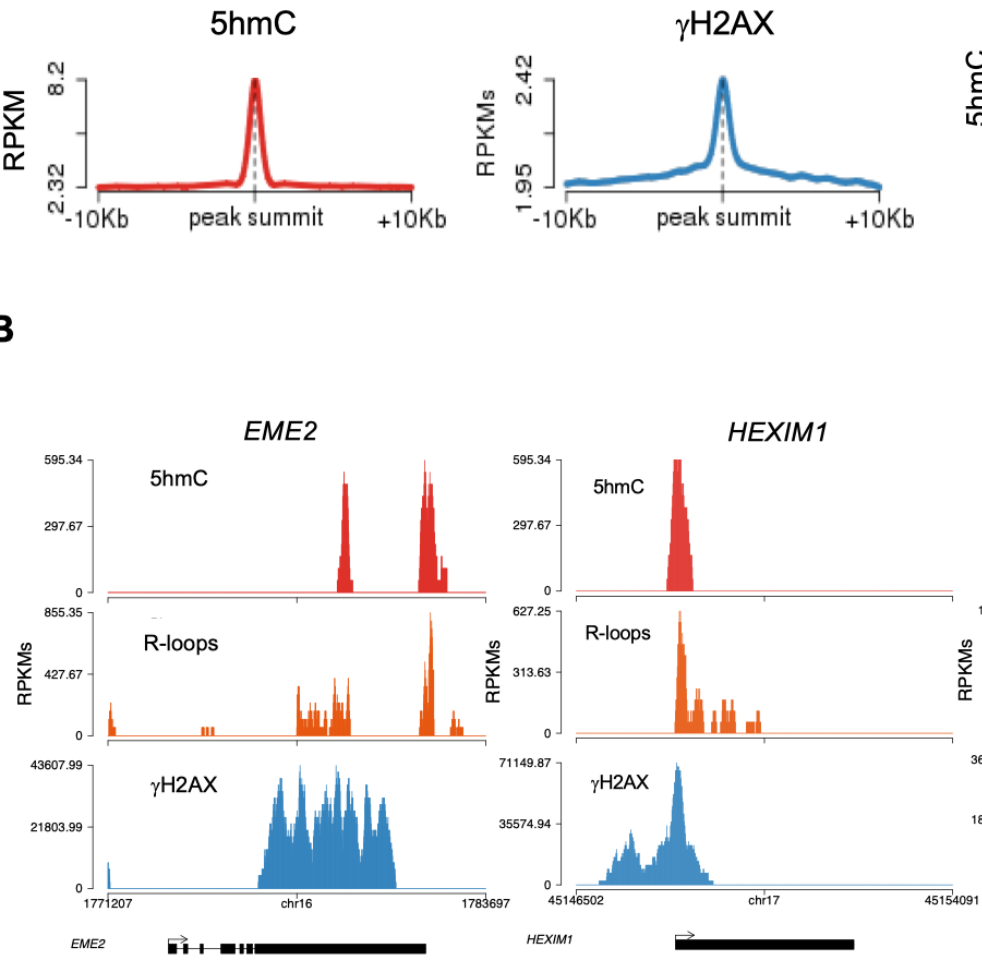

C

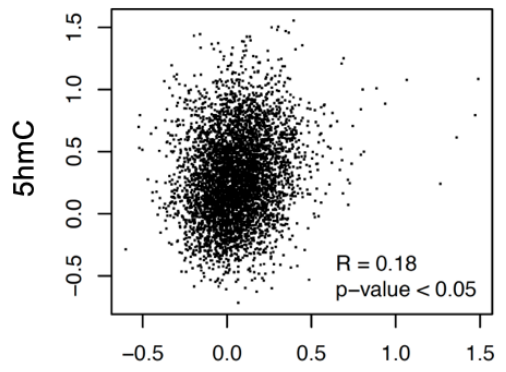

$\gamma \mathrm{H} 2 \mathrm{AX}$

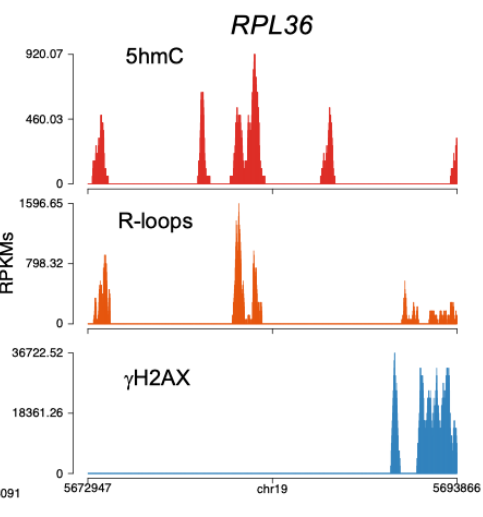

Figure 5: 5hmC-rich loci are genomic hotspots for DNA damage. (A) Metagene profiles of $5 \mathrm{hmC}$ and $\gamma \mathrm{H} 2 \mathrm{AX}$ probed over fixed windows of $\pm 10 \mathrm{kbp}$ around the $5 \mathrm{hmC}$ peaks in expressed genes of HEK293 cells. (B) Individual profiles of $5 \mathrm{hmC}, \mathrm{R}$-loops and $\mathrm{\gamma H} 2 \mathrm{AX}$ distribution along the EME2, HEXIM1 and $R P L 36$ genes. Density signals are represented as reads per kilobase (RPKMs). (C) Pearson correlation coefficient between $5 \mathrm{hmC}$ and $\mathrm{\gamma H} 2 \mathrm{AX}$ at active genes $(p<0.05)$.

R-loops formed at $5 \mathrm{hmC}$-rich regions impact the expression of genes involved in establishing diapause

264 To gather insights into the functional impact of R-loops at 5hmC-rich DNA regions, we analysed whole-transcriptome (RNA-seq) of mES cells overexpressing RNase $\mathrm{H}$, a condition resulting in genome-wide loss of R-loops ${ }^{5}$. Amongst the genes that were differentially expressed, we found that $64 \%$ and $48 \%$ of all downregulated and upregulated genes, respectively, displayed R-loops overlapping with 5hmC (Figure 6A). Pathway analysis revealed that these differentially expressed genes (Supplementary Table 1) are involved in the mechanistic target of rapamycin (mTOR) (downregulated) and MYC (upregulated) signalling pathways (Figure 6B and C). mTOR and MYC are known to play opposite roles in establishing diapause, the temporary suspension of embryonic development driven by adverse environmental conditions ${ }^{32}$, a stage that ES cells mimic when cultured in vitro. 
bioRxiv preprint doi: $\mathrm{https}$ //doi.org/10.1101/2021.04.26.441414; this version posted April 27, 2021. The copyright holder for this preprint (which was not certified by peer review) is the author/funder, who has granted bioRxiv a license to display the preprint in perpetuity. It is made available under aCC-BY 4.0 International license.

274

275

276

277

278

279

280

281

mTOR, a major nutrient sensor, acts as a rheostat during ES cell differentiation and reductions in mTOR activity trigger diapause ${ }^{33}$. This raises the hypothesis that RNase $\mathrm{H}$ impacts the proliferation of ES cells. To directly investigate this hypothesis, we overexpressed RNase $\mathrm{H}$ in mES cells. Analysis of the cellular DNA content 24 and $48 \mathrm{~h}$ after RNase $\mathrm{H}$ overexpression did not reveal any significant changes in the cell cycle progression (Supplementary Figure $2 \mathrm{~A}$ and B). This finding suggests that fine-tuned R-loop formation at specific loci, rather than global changes in R-loop levels, commands the activation of specific gene expression programs in ES cells.

A

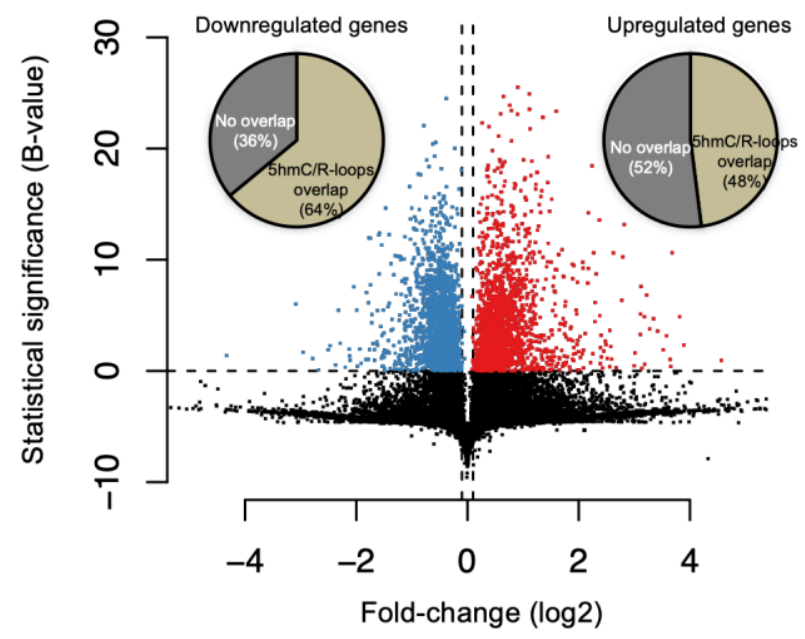

B

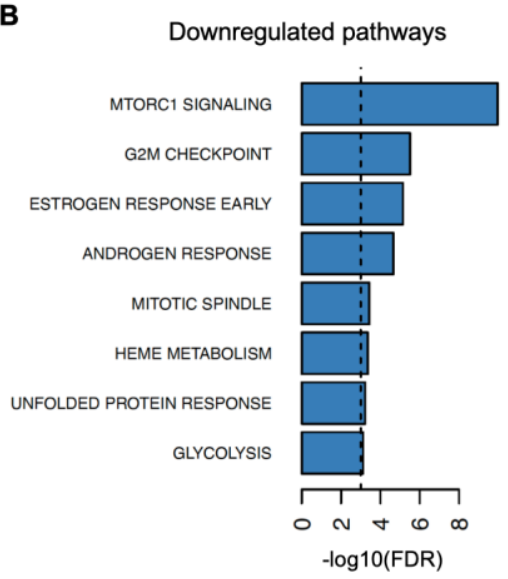

C

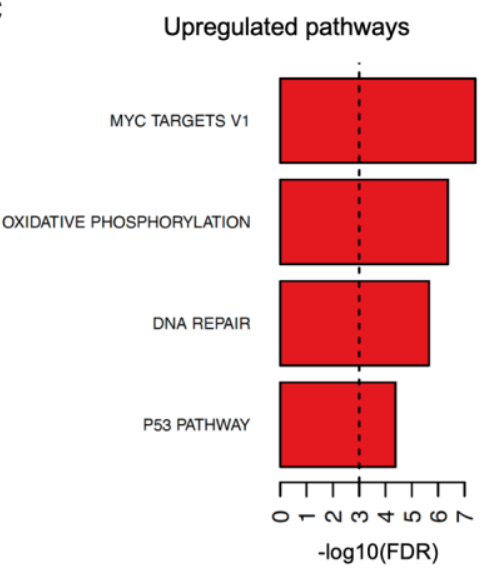

Figure 6: Cellular pathways affected by R-loops formed at $\mathbf{5 h m C}$ loci. (A) Volcano plot displaying the differentially expressed genes in $\mathrm{mES}$ cells upon RNase $\mathrm{H}$ overexpression. Of all downregulated and upregulated genes, $64 \%$ and $48 \%$ displayed R-loops overlapping with $5 \mathrm{hmC}$, respectively. (B-C) Pathway analysis of the genes that have R-loops overlapping with $5 \mathrm{hmC}$ and are differentially expressed upon RNase $\mathrm{H}$ overexpression. Shown are the significantly downregulated (B) and upregulated (C) hallmark gene sets from MSigDB. False discovery rate (FDR), $p<0.001$. 
bioRxiv preprint doi: https://doi.org/10.1101/2021.04 26.441414 this version posted April 27, 2021. The copyright holder for this preprint (which was not certified by peer review) is the author/funder, who has granted bioRxiv a license to display the preprint in perpetuity. It is made available under aCC-BY 4.0 International license.

\section{DISCUSSION}

In this study, we probed the hypothesis that $5 \mathrm{hmC}$ facilitates the co-transcriptional formation of non-canonical DNA secondary structures, known as R-loops. Data from in vitro transcription reactions and atomic force microscopy provide direct evidence showing that transcription through 5hmC-rich DNA favours R-loop formation. Using a well-established cellular model that allows the selective depletion of TET enzymes from mES cells, we demonstrate that TET activity increases endogenous R-loop levels. Notably, the diminished levels of R-loops observed in TET-depleted cells did not result from impaired transcription, suggesting that $5 \mathrm{hmC}$ directly promotes R-loop formation. In agreement, tethering TET enzymes to a specific genomic locus using a CRISPR/Cas9-based system increase the levels of R-loops at the target locus.

As R-loops play diverse physiological roles $^{1}$, our findings associate TET activity to numerous novel functions such as the regulation of gene expression, telomere homeostasis or the maintenance of genome integrity. Whether $5 \mathrm{hmC}$-editing at promoter regions or gene $3^{\prime}$ ends instructs transcription initiation or termination, respectively, through the regulation of R-loops is still to be directly investigated. Nevertheless, our finding that genome-wide $5 \mathrm{hmC}$ and R-loops overlap more robustly at the transcription termination site of active genes supports a model whereby TET enzymes act upstream of R-loop formation during transcription termination ${ }^{34}$. Telomeres, the nucleoprotein complexes found at the ends of linear eukaryotic chromosomes, can be maintained in proliferating ES and cancer cells by either the activity of telomerase or the alternative lengthening of telomeres (ALT) pathway ${ }^{35}$. ALT telomeres are maintained by mechanisms relying on homologous recombination (HR) between telomeric repeats. R-loops form extensively during transcription of telomeric-repeat-containing RNA (TERRA) and trigger a telomere specific replication stress, which promotes $\mathrm{HR}$ and re-elongation of telomeres by $\mathrm{ALT}^{36,37}$. Notably, mES cells depleted of Tet1 and/or Tet2 exhibit short telomeres and chromosomal instability, concomitant with reduced telomere recombination ${ }^{38}$. This suggests that telomeric $5 \mathrm{hmC}$ might promote HR at telomeres through the establishment of R-loops.

Owing to their link with R-loops, $5 \mathrm{hmC}$ may also harm genome integrity if not properly controlled. Indeed, we found that 5hmC-rich loci are hotspots for DNA damage genome-wide. In addition to altering the expression levels of tumour suppressors or 


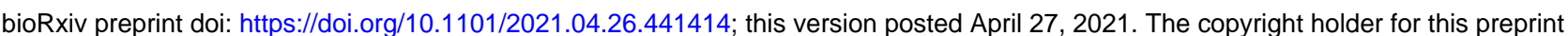
(which was not certified by peer review) is the author/funder, who has granted bioRxiv a license to display the preprint in perpetuity. It is made available under aCC-BY 4.0 International license.

oncogenes $^{39}$, our findings suggest that TET-driven changes in the DNA methylation landscape may as well drive transcription-dependent genome damaging events that could facilitate cancer development and progression. In agreement with this view, a TET1 isoform that lacks regulatory domains, including its DNA binding domain, but retains its catalytic activity is enriched in cancer cells ${ }^{40}$, suggesting that mis-targeted TET activity may drive oncogenic events, such as genomic instability. Conversely, TET activity deposits $5 \mathrm{hmC}$ at DNA damage sites induced by aphidicolin or microirradiation in HeLa cells and prevents chromosome segregation defects in response to replication stress ${ }^{41}$. Hence, TETs may play dual roles as both oncogenic and tumour suppressor genes, with the former arising as the consequence of altered expression levels or function, as observed in several cancers, such as triple-negative breast cancer ${ }^{39,42}$.

While the role that TET enzymes play during carcinogenesis is not yet clear, the impact of $5 \mathrm{hmC}$ on stem cell differentiation and development has been extensively studied $^{24}$. By driving the developmental DNA methylome reprogramming, TETs carry out numerous functions related to early developmental processes. Here, we disclose a putative new role for $\mathrm{R}$-loops as mediators of $5 \mathrm{hmC}$-driven gene expression programs that determine the self-renewal and differentiation capabilities of stem cells. Our gene ontology analysis revealed that $\mathrm{R}$-loops formed at $5 \mathrm{hmC}$-rich regions impact the expression of genes involved in establishing diapause. This stage of temporary suspension of embryonic development is triggered by adverse environmental conditions ${ }^{32}$. Accordingly, changes in the activity of mTOR, a major nutrient sensor, control ES cell commitment to trigger diapause ${ }^{33}$. The mTOR signalling pathway was significantly downregulated upon global R-loop suppression by RNase H. Conversely, MYC targets, which prevent ES cells from entering the state of dormancy that characterizes diapause ${ }^{43}$, were amongst the genes more significantly upregulated upon RNase $\mathrm{H}$ overexpression in mES cells. MYC proteins drive hypertranscription in ES cells, accelerating the gene expression output associated with increased cell proliferation ${ }^{44}$. In agreement with the view that $5 \mathrm{hmC}$-driven R-loop formation impacts functions related with $\mathrm{mES}$ cell proliferation, we observed a significant upregulation of genes involved in oxidative phosphorylation (OXPHOS), DNA repair and p53 signalling upon RNase $\mathrm{H}$ overexpression. Upregulation of OXPHOS, the main source of energy in most mammalian cells, including ES cells, may fulfil the energetic needs of ES cells 
351 resuming proliferation as they exit diapause ${ }^{45}$. Augmented expression of DNA repair and

352 p53 signalling strengthen the genome caretaker and gatekeeper mechanisms that cope with

353 the DNA damage burst observed in highly proliferative cells ${ }^{46}$. This seemingly dichotomous

354 effect of RNase $\mathrm{H}$ overexpression in ES cells (i.e. decreased mTOR and increased MYC

355 signalling, simultaneously), was further corroborated by the lack of significant changes in

356 the proliferation rate of mES cells upon RNase $\mathrm{H}$ overexpression. Whether the controlled

357 5hmC-driven formation of R-loops at specific genes, namely MYC or mTOR targets, is

358 sufficient to commit ES cells towards proliferation or establishing diapause and how do TET

359 enzymes capture the environmental cues to target R-loop formation at selected genes are

360 important questions that emerge from our findings. Thus, our data set the ground for

361 further research aimed at investigating the role of R-loops in ES cells.

362

MATERIALS AND METHODS

\section{Cell lines and culture conditions}

365 E14TG2a (E14) mouse embryonic stem (mES) cells were provided by Domingos Henrique 366 (Instituto de Medicina Molecular João Lobo Antunes), and were a gift from Austin Smith 367 (Univ. of Exeter, UK) ${ }^{47}$. 129S4/SvJae (J1) mES cells were kindly provided by Joana Marques

368 (Medical School, University of Porto). Cells were grown as monolayers on 0,1\% gelatine 369 (410875000, Acros Organics) coated dishes, using Glasgow Modified Eagle's Medium 370 (GMEM) (21710-025, Gibco), supplemented with 1\% (v/v) 200mM L-glutamine (25030-024, 371 Thermo Scientific), 1\% (v/v) 100mM sodium pyruvate (11360-039, Gibco), 1\% (v/v) 100x non-essential aminoacids solution (11140-035, Gibco), 0,1\% (v/v) 0,1M 2-mercaptoethanol

373 (M7522, Sigma Aldrich), 1\% (v/v) penicillin-streptomycin solution (15070-063, Gibco) and $37410 \%(v / v)$ heat-inactivated, ES-qualified FBS (SH30070, Cytiva). Medium was filtered through 375 a $0,22 \mu \mathrm{m}$ filter. Home-produced leukaemia inhibitory factor (LIF) was added to the medium 376 upon plating, at $6 \times 10^{-2} \mathrm{ng} / \mu \mathrm{L}$. U2OS osteosarcoma and HEK293T embryonic kidney cells 377 (purchased from ATCC) were grown as monolayers in Dulbecco's Modified Eagle medium 378 (DMEM) (21969-035, Gibco), supplemented with 1\% (v/v) 200mM L-glutamine (25030-024, 379 Thermo Scientific), 1\% (v/v) penicillin-streptomycin solution (15070-063, Gibco) and 10\% 
bioRxiv preprint doi: https://doi.org/10.1101/2021.04 26.441414 - this version posted April 27, 2021. The copyright holder for this preprint (which was not certified by peer review) is the author/funder, who has granted bioRxiv a license to display the preprint in perpetuity. It is made available under aCC-BY 4.0 International license.

380 (v/v) FBS (10270106, Gibco). All cells were maintained at $37^{\circ} \mathrm{C}$ in a humidified atmosphere 381 with $5 \% \mathrm{CO}_{2}$.

\section{Tet knockdown}

383 J1 mES cells with doxycycline-inducible short hairpin RNA-micro RNA (shRNA 384 Supplementary Table 2) sequences targeting Tet1 or Tet3 were treated for $48 \mathrm{~h}$ with 2 $385 \mu \mathrm{g} / \mathrm{mL}$ doxycycline (D9891, Sigma Aldrich).

\section{RNA isolation and quantitative RT-PCR}

Total RNA was isolated from J1 mES cells under doxycycline treatment for $48 \mathrm{~h}$, using TRIzol reagent (15596018, Invitrogen). cDNA was prepared through reverse transcriptase activity (MB125, NZYTech). RT-qPCR was performed in the ViiA 7 Real-Time PCR system (Applied Biosystems), using PowerUp SYBR Green Master Mix (A25918, Applied Biosystems). The relative RNA expression was estimated as follows: $2^{\text {(Ct reference - Ct sample) }}$, where $\mathrm{Ct}$ reference and Ct sample are mean threshold cycles of RT-qPCR done in duplicate for the U6 snRNA or Gapdh and for the gene of interest, respectively. Primer sequences are presented in

\section{Supplementary Table 3.}

\section{R-loops dot blot}

396 J1 mES cells were collected after $48 \mathrm{~h}$ of doxycycline treatment and lysed in lysis buffer

397 (100mM NaCl, 10mM Tris pH 8.0,25mM EDTA pH 8.0, 0,5\% SDS, 50 $\mu \mathrm{g} / \mathrm{mL}$ Proteinase K)

398 overnight at $37^{\circ} \mathrm{C}$. Nucleic acids were extracted using standard phenol-chloroform extraction protocol and re-suspended in DNase/RNase-free water. Nucleic acids were then

400 fragmented using a restriction enzyme cocktail (20U each of EcoRI, BamHI, HindIII, BsrgI and 401 Xhol). Half of the sample was digested with $40 \mathrm{U}$ RNase $\mathrm{H}$ (MB085, NZYTech) to serve as 402 negative control, for about $36-48 \mathrm{~h}$ at $37{ }^{\circ} \mathrm{C}$. Digested nucleic acids were cleaned with 403 standard phenol-chloroform extraction and res-suspended in DNase/RNase-free water. 404 Nucleic acids samples were quantified in a NanoDrop 2000 spectrophotometer (Thermo 405 Scientific), and equal amounts of DNA were deposited into a positively charged nylon 406 membrane (RPN203B, GE Healthcare). Membranes were UV-crosslinked using UV 407 Stratalinker 2400 (Stratagene), blocked in 5\% (m/v) milk in PBSt (PBS 1× containing 0.05\% 
bioRxiv preprint doi: https://doi.org/10.1101/2021.04 26.441414 this version posted April 27, 2021. The copyright holder for this preprint (which was not certified by peer review) is the author/funder, who has granted bioRxiv a license to display the preprint in perpetuity. It is made available under aCC-BY 4.0 International license.

408 (v/v) Tween 20) for $1 \mathrm{~h}$ at room temperature, and immunoblotted with specific antibodies.

409 Details of antibodies used are included in Supplementary Table 4.

\section{$410 \quad 5 \mathrm{mC}$ and $5 \mathrm{hmC}$ dot blot}

411 J1 mES cells were collected after $48 \mathrm{~h}$ of doxycycline treatment and lysed in lysis buffer $412(100 \mathrm{mM} \mathrm{NaCl}, 10 \mathrm{mM}$ Tris $\mathrm{pH} 8.0,25 \mathrm{mM}$ EDTA pH 8.0, 0.5\% SDS, $50 \mu \mathrm{g} / \mathrm{mL}$ Proteinase $\mathrm{K})$ for $4132 \mathrm{~h}$ at $56^{\circ} \mathrm{C}$. Samples were sonicated with $4-6$ pulses of $15 \mathrm{~s}$ at $10 \mathrm{~mA}$ intensity using a 414 Soniprep150 sonicator (keeping tubes for at least $1 \mathrm{~min}$ on ice between pulses) to shear 415 chromatin into 100-300bp fragments. Fragmented nucleic acids were cleaned with standard 416 phenol-chloroform extraction method and re-suspended in DNase/RNase-free water. DNA 417 was resolved in agarose gels to confirm fragment size. Samples were denatured by boiling at $418100^{\circ} \mathrm{C}$ for $10 \mathrm{~min}$, followed by immediate chilling on ice and quick spin, and deposited into a 419 nylon membrane (the sample fraction used for dsDNA detection was not subject to boiling), 420 prior to UV-crosslinking and immunoblotting. Details of antibodies used are included in 421 Supplementary Table 4.

$423 \mathrm{~J} 1 \mathrm{mES}$ cells were grown on glass coverslips and incubated for $1 \mathrm{~h}\left(37^{\circ} \mathrm{C}, 5 \% \mathrm{CO}_{2}\right)$ with EU 424 from the Click-iT RNA Alexa Fluor 594 imaging kit (C10330, Invitrogen). Cells were fixed with $4253,7 \%$ formaldehyde in PBS $1 \times$ for $15 \mathrm{~min}$ at room temperature and permeabilized with $0.5 \%$ 426 Triton $\mathrm{X}-100$ in PBS $1 \times$ for $15 \mathrm{~min}$ at room temperature. The Click-It reaction using a 427 fluorescent azide (Alexa Fluor 594 azide) was then performed according to manufacturer's 428 instructions (30min at room temperature, protected from light). Finally, nuclear staining 429 was performed with Hoechst 33342 1:1000 in PBS 1× for 10min at room temperature, and 430 coverslips were assembled in Vectashield (Vector Laboratories) mounting medium. Cells 431 were imaged using a point-scanning confocal microscope Zeiss LSM 880, 63×/1.4 oil 432 immersion, with stacking acquisition and generation of maximum intensity projection 433 images. Nucleoplasmic fluorescence intensity measurements were performed using ImageJ. 
E14 mES cells were grown on coverslips for $48 \mathrm{~h}$, and fixed/permeabilized with methanol for $10 \mathrm{~min}$ on ice, followed by $1 \mathrm{~min}$ acetone on ice. Cells were then incubated with both primary antibodies simultaneously for $1 \mathrm{~h}$ at $37^{\circ} \mathrm{C}$, followed by a pre-mixed solution of PLA probe anti-mouse minus (DU092004, Sigma Aldrich) and PLA probe anti-rabbit plus (DUO92002, Sigma Aldrich) for $1 \mathrm{~h}$ at $37^{\circ} \mathrm{C}$. Localized rolling circle amplification was performed using

440 Detection Reagents Red (DU092008, Sigma Aldrich), according to the manufacturer's instructions. Slides were mounted in 1:1000 DAPI in Vectashield. Images were acquired using the Point Scanning Confocal Microscope Zeiss LSM 880, 63x/1,4 oil immersion, with stacking acquisition and generation of maximum intensity projection images. The number of PLA foci was quantified using ImageJ. Details of antibodies used are mentioned in

\section{Supplementary Table 4.}

g-blocks PCR

447 Designed g-blocks were ordered from IDT (Supplementary Table 5), and PCR-amplified 448 using Phusion High-Fidelity DNA Polymerase (M0530S, NEB), according to manufacturer's 449 instructions. M13 primers were used to amplify all fragments (Supplementary Table 3), in 450 the presence of dNTP mixes containing native (MB08701, NZYTech), methylated (D1030, 451 Zymo Research) or hydroxymethylated (D1040, Zymo Research) cytosines. Efficient 452 incorporation of modified dCTPs was confirmed through immunoblotting with specific antibodies. Details of antibodies used are mentioned in Supplementary Table 4.

\section{In vitro transcription}

PCR products were subject to in vitro transcription using the HiScribe T7 High Yield RNA Synthesis Kit (E2040S, NEB), which relies on the T7 RNA polymerase to initiate transcription from a T7 promoter sequence (present in our fragments). Reactions were performed for $2 \mathrm{~h}$ at $37^{\circ} \mathrm{C}$, using $1 \mu \mathrm{g}$ of DNA as template, according to manufacturer's instructions.

\section{S9.6 immunoblotting of in vitro transcription products}

Half of each in vitro transcription product was treated with 10U RNase H (MB085, NZYTech) 
agarose gel. Nucleic acids were transferred to a nylon membrane through capillary transfer, overnight at room temperature. The membrane was then UV-crosslinked twice, blocked in $5 \%$ milk in PBSt for $1 \mathrm{~h}$ at room temperature, and incubated with the primary antibody at 4으 overnight. Signal quantification was performed using Image Lab. Details of antibodies used are included in Supplementary Table 4.

\section{Atomic Force Microscopy}

RNase A-treated in vitro transcription products, treated or not with RNase $\mathrm{H}$, were purified through phenol-chloroform extraction method and re-suspended in DNase/RNase-free water. DNA solution was diluted 1:10 in Sigma ultrapure water (with final $10 \mathrm{mM} \mathrm{MgCl}$ ) and briefly mixed to ensure even dispersal in solution. A $10 \mu \mathrm{L}$ droplet was deposited at the centre of a freshly cleaved mica disc, ensuring that the pipette tip did not contact the mica substrate. The solution was let to adsorb on mica surface for 1-2min to ensure adequate coverage. The mica surface was carefully rinsed with Sigma ultrapure water, so that excess of poorly bound DNA to mica is removed from the mica substrate. Afterwards, the mica substrate was dried under a gentle stream of argon gas for approximately 2 min, making sure that any excess water is removed. DNA imaging was performed using a JPK Nanowizard IV atomic force microscope, mounted on a Zeiss Axiovert 200 inverted optical microscope. Measurements were carried out in tapping mode using commercially available ACT cantilevers (AppNano). After selecting a region of interest, the DNA was scanned in air, with scan rates between 0.5 and $0.9 \mathrm{~Hz}$. The setpoint selected was close to $0.3 \mathrm{~V}$. Several images from different areas of the same sample were performed and at least three independent samples for each condition were imaged. All images were of $512 \times 512$ pixels and analysed with JPK data processing software.

\section{Lentiviral transduction}

487 Lentivirus containing dCas9-TET1 (\#84475, Addgene) or dCas9-dTET1 (\#84479, Addgene) 488 coding plasmids, as well as one out of three gRNAs (gRNA_1, 2 and 3) coding plasmids 489 designed for the APOE last exon, were produced. HEK293T cells were transfected with the 490 above-mentioned plasmids, as well as with the $\Delta 8.9$ and VSV-g plasmids (for virus 491 assembly). Virus production occurred for $48 \mathrm{~h}$, after which culture supernatant was collected 
and filtered through a $0.45 \mu \mathrm{m}$ filter. Lentivirus were collected through ultracentrifugation (25000 rpm, 3h, $4^{\circ} \mathrm{C}$ ) using a SW-41Ti rotor in a Beckman XL-90 ultracentrifuge. Virus were re-suspended in PBS $1 \times$ and stored at $-80^{\circ} \mathrm{C}$. For infection, a pool of lentivirus containing dCas9-TET1 or dCas9-dTET1, as well as gRNA_1, 2 or 3 coding plasmids, was used to infect seeded U2OS cells. After $24 \mathrm{~h}$, antibiotic selection was performed with $1.5 \mu \mathrm{g} / \mathrm{mL}$ puromycin, and infection proceeded for more 48h. 3 days post-infection, cells were harvested and genomic DNA was extracted for subsequent protocols.

\section{DNA:RNA Immunoprecipitation (DRIP)}

Infected U2OS cells were collected and lysed in lysis buffer $(100 \mathrm{mM} \mathrm{NaCl}, 10 \mathrm{mM}$ Tris pH 8.0, $25 \mathrm{mM}$ EDTA, $0.5 \% \mathrm{SDS}, 50 \mu \mathrm{g} / \mathrm{mL}$ Proteinase $\mathrm{K}$ ) overnight at $37^{\circ} \mathrm{C}$. Nucleic acids were extracted using standard phenol-chloroform extraction protocol and re-suspended in DNase/RNase-free water. Nucleic acids were then fragmented using a restriction enzyme cocktail (20U each of EcoRI, BamHI, HindIII, Bsrgl and Xhol), and 10\% of the digested sample was kept aside to use later as input. Half of the remaining volume was digested with $40 \mathrm{U}$ RNase $\mathrm{H}$ (MB085, NZYTech) to serve as negative control, for $72 \mathrm{~h}$ at $37^{\circ} \mathrm{C}$. Digested nucleic acids were cleaned with standard phenol-chloroform extraction and re-suspended in DNase/RNase-free water. RNA:DNA hybrids were immunoprecipitated from total nucleic acids using $5 \mu \mathrm{g}$ of S9.6 antibody (MABE1095, Merck Millipore) in binding buffer (10mM $\mathrm{Na}_{2} \mathrm{HPO}_{4} \mathrm{pH} 7.0,140 \mathrm{mM} \mathrm{NaCl}, 0.05 \%$ Triton X-100), overnight at $4^{\circ} \mathrm{C}$. $50 \mu \mathrm{l}$ protein $\mathrm{G}$ magnetic beads (10004D, Invitrogen) were used to pull-down the immune complexes at $4{ }^{\circ} \mathrm{C}$ for 2-3h. Isolated complexes were washed 5 times (for 1 min on ice) with binding buffer and once with Tris-EDTA (TE) buffer (10mM Tris pH 8.1, 1mM EDTA). Elution was performed in two steps, for $15 \mathrm{~min}$ at $55^{\circ} \mathrm{C}$ each, using elution buffer $(50 \mathrm{mM}$ Tris $\mathrm{pH} 8.0,10 \mathrm{mM}$ EDTA, $0.5 \%$ SDS, $60 \mu \mathrm{g} / \mathrm{mL}$ Proteinase K). The relative occupancy of DNA:RNA hybrids was estimated by RT-qPCR as follows: $2^{\text {(Ct Input-Ct IP) }}$, where $\mathrm{Ct}$ Input and Ct IP are mean threshold cycles of RT-qPCR done in duplicate for input samples and specific immunoprecipitations, respectively. Primer sequences are presented in Supplementary Table 3.

\section{5-(hydroxy)Methylated DNA Immunoprecipitation ((h)MeDIP)}


bioRxiv preprint doi: https://doi.org/10.1101/2021.04 26.441414 this version posted April 27, 2021. The copyright holder for this preprint (which was not certified by peer review) is the author/funder, who has granted bioRxiv a license to display the preprint in perpetuity. It is made available under aCC-BY 4.0 International license.

520 Infected U2OS cells were collected and lysed in lysis buffer overnight at $37^{\circ} \mathrm{C}$. Samples were 521 sonicated with 4 pulses of $15 \mathrm{~s}$ at $10 \mathrm{~mA}$ intensity using a Soniprep150 sonicator (keeping 522 tubes for at least 1 min on ice between pulses). Fragmented nucleic acids were cleaned with standard phenol-chloroform extraction protocol and res-suspended in DNase/RNase-free water. $10 \%$ of sample was kept aside to use later as input. The remaining volume was denatured by boiling the samples at $100^{\circ} \mathrm{C}$ for $10 \mathrm{~min}$, followed by immediate chilling on ice and quick spin. Samples were divided in half, and $5 \mu \mathrm{g}$ of anti-5mC antibody (61255, Active Motif) or $5 \mu \mathrm{g}$ of anti-5hmC antibody (39791, Active Motif) were used to immunoprecipitate $5 \mathrm{mC}$ and $5 \mathrm{hmC}$, respectively, in binding buffer, overnight at $4^{\circ} \mathrm{C} .50 \mu$ protein $\mathrm{G}$ magnetic beads (10004D, Invitrogen) were used to pull-down the immune complexes at $4{ }^{\circ} \mathrm{C}$ for $2-3 \mathrm{~h}$. Isolated complexes were washed 5 times (for 1 min on ice) with binding buffer and once with TE buffer. Elution was performed in two steps, for $15 \mathrm{~min}$ at $55^{\circ} \mathrm{C}$ each, using elution buffer. The relative occupancy of $5 \mathrm{mC}$ and $5 \mathrm{hmC}$ was estimated by RT-qPCR. Primer sequences are presented in Supplementary Table 3.

\section{Cell cycle analysis}

535 pEGFP-N1 (GFP coding plasmid used as control) was purchased from Addgene, and pEGFP536 RNaseH1 (GFP-tagged RNase H1 coding plasmid) was kindly provided by Robert J. Crouch 537 (NIH, USA). Seeded mES cells were transfected with GFP (control) or GFP-tagged RNase H 538 coding plasmids. 24 or $48 \mathrm{~h}$ later, cells were trypsinized and pelleted by centrifugation at $539500 \times g$ for $5 \mathrm{~min}$. Cells were fixed in cold $1 \%$ PFA for $20 \mathrm{~min}$ at $4{ }^{\circ} \mathrm{C}$, followed by 540 permeabilization in $70 \%$ ethanol for $1 \mathrm{~h}$ at $4{ }^{\circ} \mathrm{C}$. Cells were then treated with $25 \mu \mathrm{g} / \mathrm{mL}$ RNase 541 A (10109142001, Roche) in PBS $1 \times$ at $37^{\circ} \mathrm{C}$ for $20 \mathrm{~min}$, followed by staining with $20 \mu \mathrm{g} / \mathrm{mL}$ 542 propidium iodide (P4864, Sigma Aldrich) in PBS $1 \times$ for $10 \mathrm{~min}$ at $4^{\circ} \mathrm{C}$. Flow cytometry was 543 performed on a BD Accuri C6 (BD Biosciences) and data were analysed using FlowJo 544 software.

\section{Multi-omics data}

546 High-throughput sequencing (HTS) data for mES cells and HEK293 cells were gathered from 547 GEO archive: transcriptome of mES cells (GSE67583); R-loops in mES cells (GSE67581); 5hmC 548 in mES cells (GSE31343); $\gamma \mathrm{H} 2 \mathrm{AX}$ in mES cells (GSE69140); active transcription in HEK293 
bioRxiv preprint doi: https://doi.org/10.1101/2021.04 26.441414 this version posted April 27, 2021. The copyright holder for this preprint (which was not certified by peer review) is the author/funder, who has granted bioRxiv a license to display the preprint in perpetuity. It is made available under aCC-BY 4.0 International license.

549 (GRO-seq, GSE51633); R-loops in HEK293 (DRIP-seq, GSE68948); 5hmC modification in 550 HEK293 (hMeDIP-seq, GSE44036); yH2AX (ChIP-seq, GSE75170). Transcriptome profiles of mES cells overexpressing RNase $\mathrm{H}$ were obtained from GSE67583. The quality of HTS data was assessed with FastQC (www.bioinformatics.babraham.ac.uk/projects/fastqc).

\section{5hmC, R-loop and yH2AX genome-wide characterization}

554 The HTS datasets produced by immunoprecipitation (DRIP-seq, ChIP-seq and hMeDIP-seq) were analysed through the same workflow. First, the reads were aligned to the reference mouse and human genome (mm10 and GRCh38/hg38 assemblies, respectively) with Bowtie $^{48}$, and filtering for uniquely aligned reads. Enriched regions were identified relative to the input samples using $\mathrm{MACS}^{49}$, with a false-discovery rate of 0,05 . Finally, enriched regions were assigned to annotated genes, including a 4-kilobase region upstream the

560 transcription start site and downstream the transcription termination site. Gene annotations were obtained from mouse and human Gencode annotations (M11 and v23 versions, respectively) and merged into a single transcript model per gene using BedTools ${ }^{50}$.

563 For individual and metaprofiles, uniquely mapped reads were extended in the $3^{\prime}$ direction to reach $150 \mathrm{nt}$ with the Pyicos ${ }^{51}$. Individual profiles were produced using a 20bp window. For the metaprofiles centered around $5 \mathrm{hmC}$ peaks: $5 \mathrm{hmc}$ enriched regions were aligned by the peak summit (maximum of the peak) and the read density for the flanking $10 \mathrm{kbp}$ were averaged in a $200 \mathrm{bp}$ window. For the metagene profiles: the gene body region was scaled to 60 equally sized bins and $\pm 10 \mathrm{kbp}$ gene-flanking regions were averaged in $200 \mathrm{bp}$ windows. All profiles were plotted as normalized reads per kilobase per million mapped reads (RPKMs). A set of in-house scripts for data processing and graphical visualization were written in bash and in the $\mathrm{R}$ environmental language http://www.R-project.org ${ }^{52}$. SAMtools $s^{53}$ and BEDtools were used for alignment manipulation, filtering steps, file format conversion and comparison of genomic features. Statistical significance of the overlap between $5 \mathrm{hmC}$ regions and R-loops was assessed by permutation analysis. Briefly, random $5 \mathrm{hmC}$ and R-loops datasets were generated 1000 times from annotated genes using the shuffle BEDtools function (maintaining the number and length of the originally datasets).

577 The $p$-value was determined as the frequency of overlapping regions between the random datasets as extreme as the observed. 


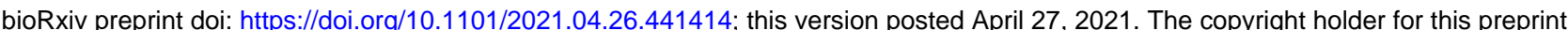
(which was not certified by peer review) is the author/funder, who has granted bioRxiv a license to display the preprint in perpetuity. It is made available under aCC-BY 4.0 International license.

\section{Transcriptome analysis}

Expression levels (Transcripts per Million, TPMs) from RNA-seq and GRO-seq datasets were obtained using Kallisto ${ }^{54}$, where reads were pseudo-aligned to mouse and human Gencode transcriptomes (M11 and v23, respectively). Transcriptionally active genes for $5 \mathrm{hmC}$ and Rloops annotation were defined as those with expression levels higher than the $25^{\text {th }}$ percentile. Differential expression in $\mathrm{mES}$ cells overexpressing RNase $\mathrm{H}$ was assessed using edgeR (v3.20.9) and limma (v3.34.9) R packages ${ }^{55,56}$. Briefly, samples comparison was performed using voom transformed values, linear modelling and moderated T-test as implemented in limma R package, selecting significantly differentially expressed genes with B-statistics higher than zero. Significantly enriched pathways of up and down-regulated genes (with overlapping R-loops/5hmC regions) were selected using Fisher's Exact Test and all expressed genes as background gene list. Evaluated pathways were obtained from the hallmark gene sets of Molecular Signatures Database (MSigDB $)^{57}$ and filtered using False discovery rate corrected $p$-values $<0,05$.

\section{ACKNOWLEDGMENTS}

We thank our colleagues, Joana Marques, Domingos Henrique and Robert Crouch for kind gifts of cell lines, plasmids and reagents. This work was funded by PTDC/BIAMOL/30438/2017 and PTDC/MED-OUT/4301/2020 from Fundação para a Ciência e Tecnologia (FCT), Portugal. Funding was also received from EU Horizon 2020 Research and Innovation Programme (RiboMed 857119). J.C.S. is the recipient of an FCT PhD fellowship $\mathrm{PD} / \mathrm{BD} / 128292 / 2017$.

\section{REFERENCES}

1. García-Muse, T. \& Aguilera, A. R Loops: From Physiological to Pathological Roles. Cell

2. Sridhara, S. C. et al. Transcription Dynamics Prevent RNA-Mediated Genomic Instability through SRPK2-Dependent DDX23 Phosphorylation. Cell Rep. 18, 334-343 (2017).

3. Bonnet, A. et al. Introns Protect Eukaryotic Genomes from Transcription-Associated 


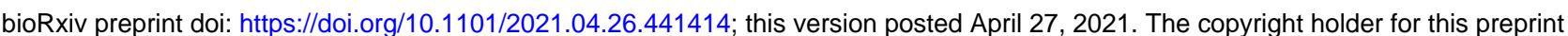
(which was not certified by peer review) is the author/funder, who has granted bioRxiv a license to display the preprint in perpetuity. It is made available under aCC-BY 4.0 International license.

609

610

611

612

613

614

615

616

617

618

619

620

621

622

623

624

625

626

627

628

629

630

631

632

633

634

635

636

637

638

639

640

641

642

643

644

645

646

647

648

649

Genetic Instability. Mol. Cell 67, 608-621 (2017).

4. Ginno, P. A., Lim, Y. W., Lott, P. L., Korf, I. \& Chédin, F. GC skew at the 5' and 3' ends of human genes links R-loop formation to epigenetic regulation and transcription termination. Genome Res. 23, 1590-1600 (2013).

5. Chen, P. B., Chen, H. V, Acharya, D., Rando, O. J. \& Fazzio, T. G. R loops regulate promoter-proximal chromatin architecture and cellular differentiation. Nat. Struct. Mol. Biol. 22, 999-1007 (2015).

6. Skourti-Stathaki, K. \& Proudfoot, N. J. A double-edged sword: R loops as threats to genome integrity and powerful regulators of gene expression. Genes Dev. 28, 13841396 (2014).

7. Chédin, F. Nascent Connections: R-Loops and Chromatin Patterning. Trends Genet. 32, 828-838 (2016).

8. Skourti-Stathaki, K., Kamieniarz-Gdula, K. \& Proudfoot, N. J. R-loops induce repressive chromatin marks over mammalian gene terminators. Nature 516, 436-439 (2014).

9. Ginno, P. A., Lott, P. L., Christensen, H. C., Korf, I. \& Chédin, F. R-Loop Formation Is a Distinctive Characteristic of Unmethylated Human CpG Island Promoters. Mol. Cell 45, 814-825 (2012).

10. Jin, B. \& Robertson, K. D. DNA Methyltransferases (DNMTs), DNA Damage Repair, and Cancer. in Advances in experimental medicine and biology 754, 3-29 (NIH Public Access, 2013).

11. Greenberg, M. V. C. \& Bourc'his, D. The diverse roles of DNA methylation in mammalian development and disease. Nat. Rev. Mol. Cell Biol. 20, 590-607 (2019).

12. Weber, M. et al. Distribution, silencing potential and evolutionary impact of promoter DNA methylation in the human genome. Nat. Genet. 39, 457-466 (2007).

13. Grunseich, C. et al. Senataxin Mutation Reveals How R-Loops Promote Transcription by Blocking DNA Methylation at Gene Promoters. Mol. Cell 69, 426-437 (2018).

14. Arab, K. et al. GADD45A binds R-loops and recruits TET1 to CpG island promoters. Nat. Genet. 51, 217-223 (2019).

15. Pastor, W. A., Aravind, L. \& Rao, A. TETonic shift: biological roles of TET proteins in DNA demethylation and transcription. Nat. Rev. Mol. Cell Biol. 14, 341-356 (2013).

16. Tahiliani, M. et al. Conversion of 5-methylcytosine to 5-hydroxymethylcytosine in mammalian DNA by MLL partner TET1. Science (80-. ). 324, 930-935 (2009).

17. Mendonca, A., Chang, E. H., Liu, W. \& Yuan, C. Hydroxymethylation of DNA influences nucleosomal conformation and stability in vitro. Biochim. Biophys. Acta 1839, 13231329 (2014).

18. Wu, H. et al. Genome-wide analysis of 5-hydroxymethylcytosine distribution reveals its dual function in transcriptional regulation in mouse embryonic stem cells. Genes Cancer 25, 679-684 (2011).

19. Hahn, M. A. et al. Dynamics of 5-Hydroxymethylcytosine and Chromatin Marks in Mammalian Neurogenesis. Cell Rep. 3, 291-300 (2013).

20. Leavitt, R., Yen, J. \& Jia, X.-Y. 5-methylcytosine and 5-hydroxymethylcytosine Exert 
bioRxiv preprint doi: https://doi.org/10 1101/2021.04 26.441414 this version posted April 27, 2021. The copyright holder for this preprint (which was not certified by peer review) is the author/funder, who has granted bioRxiv a license to display the preprint in perpetuity. It is made available under aCC-BY 4.0 International license.

650

651

652

653

654

655

656

657

658

659

660

661

662

663

664

665

666

667

668

669

670

671

672

673

674

675

676

677

678

679

680

681

682

683

684

685

686

687

688

689

690

Opposite Forces on Base Pairing of DNA Double Helix. Zymo Research Corporation 67 (2015).

21. Wanunu, M. et al. Discrimination of methylcytosine from hydroxymethylcytosine in DNA molecules. J. Am. Chem. Soc. 133, 486-492 (2011).

22. Carrasco-Salas, Y. et al. The extruded non-template strand determines the architecture of R-loops. Nucleic Acids Res. 47, 6783-6795 (2019).

23. Klinov, D. V et al. High resolution mapping DNAs by R-loop atomic force microscopy. Nucleic Acids Res. 26, 4603-4610 (1998).

24. Ficz, G. et al. Dynamic regulation of 5-hydroxymethylcytosine in mouse ES cells and during differentiation. Nature 473, 398-404 (2011).

25. Liu, X. S. et al. Editing DNA Methylation in the Mammalian Genome. Cell 167, 233247 (2016).

26. Matarese, F., Carrillo-De Santa Pau, E. \& Stunnenberg, H. G. 5Hydroxymethylcytosine: a new kid on the epigenetic block? Mol. Syst. Biol. 7, (2011).

27. Jin, C. et al. TET1 is a maintenance DNA demethylase that prevents methylation spreading in differentiated cells. Nucleic Acids Res. 42, 6956-6971 (2014).

28. Nadel, J. et al. RNA:DNA hybrids in the human genome have distinctive nucleotide characteristics, chromatin composition, and transcriptional relationships. Epigenetics Chromatin 8, (2015).

29. Hamperl, S., Bocek, M. J., Saldivar, J. C., Swigut, T. \& Cimprich, K. A. TranscriptionReplication Conflict Orientation Modulates R-Loop Levels and Activates Distinct DNA Damage Responses. Cell 170, 774-786 (2017).

30. Helmrich, A., Ballarino, M., Nudler, E. \& Tora, L. Transcription-replication encounters, consequences and genomic instability. Nat. Struct. Mol. Biol. 20, 412-418 (2013).

31. Bunch, H. et al. Transcriptional elongation requires DNA break-induced signalling. Nat. Commun. 6, (2015).

32. Fenelon, J. C., Banerjee, A. \& Murphy, B. D. Embryonic diapause: development on hold. Int. J. Dev. Biol. 58, 163-174 (2014).

33. Bulut-Karslioglu, A. et al. Inhibition of mTOR induces a paused pluripotent state. Nature 540, 119-123 (2016).

34. Skourti-Stathaki, K., Proudfoot, N. J. \& Gromak, N. Human Senataxin Resolves RNA/DNA Hybrids Formed at Transcriptional Pause Sites to Promote Xrn2-Dependent Termination. Mol. Cell 42, 794-805 (2011).

35. Claude, E. \& Decottignies, A. Telomere maintenance mechanisms in cancer: telomerase, ALT or lack thereof. Curr. Opin. Genet. Dev. 60, 1-8 (2020).

36. Arora, R. et al. RNaseH1 regulates TERRA-telomeric DNA hybrids and telomere maintenance in ALT tumour cells. Nat. Commun. 5, 1-11 (2014).

37. Domingues-Silva, B., Silva, B. \& Azzalin, C. M. ALTernative Functions for Human FANCM at Telomeres. Front. Mol. Biosci. 6, (2019).

38. Yang, J. et al. Tet Enzymes Regulate Telomere Maintenance and Chromosomal Stability of Mouse ESCs. Cell Rep. 15, 1809-1821 (2016). 


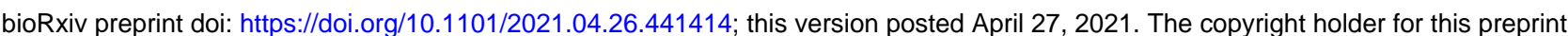
(which was not certified by peer review) is the author/funder, who has granted bioRxiv a license to display the preprint in perpetuity. It is made available under aCC-BY 4.0 International license.

691

692

693

694

695

696

697

698

699

700

701

702

703

704

705

706

707

708

709

710

711

712

713

714

715

716

717

718

719

720

721

722

723

724

725

726

727

728

729

730

731

39. Bray, J. K., Dawlaty, M. M., Verma, A. \& Maitra, A. Roles and Regulations of TET

Enzymes in Solid Tumors. Trends in Cancer (2021). doi:10.1016/j.trecan.2020.12.011

40. Good, C. R. et al. A novel isoform of TET1 that lacks a CXXC domain is overexpressed in cancer. Nucleic Acids Res. 45, 8269-8281 (2017).

41. Kafer, G. R. et al. 5-Hydroxymethylcytosine Marks Sites of DNA Damage and Promotes Genome Stability. Cell Rep. 14, 1283-1292 (2016).

42. Good, C. R. et al. TET1-Mediated Hypomethylation Activates Oncogenic Signaling in Triple-Negative Breast Cancer. Cancer Res. 78, 4126-4137 (2018).

43. Scognamiglio, R. et al. Myc Depletion Induces a Pluripotent Dormant State Mimicking Diapause. Cell 164, 668-680 (2016).

44. Percharde, M., Bulut-Karslioglu, A. \& Ramalho-Santos, M. Hypertranscription in Development, Stem Cells, and Regeneration. Dev. Cell 40, 9-21 (2017).

45. Mathieu, J. \& Ruohola-Baker, H. Metabolic remodeling during the loss and acquisition of pluripotency. Development 144, 541-551 (2017).

46. Williams, A. B. \& Schumacher, B. p53 in the DNA-Damage-Repair Process. Cold Spring Harb. Perspect. Med. 1-15 (2016).

47. Smith, A. G. \& Hooper, M. L. Buffalo rat liver cells produce a diffusible activity which inhibits the differentiation of murine embryonal carcinoma and embryonic stem cells. Dev. Biol. 121, 1-9 (1987).

48. Langmead, B., Trapnell, C., Pop, M. \& Salzberg, S. L. Ultrafast and memory-efficient alignment of short DNA sequences to the human genome. Genome Biol. 10, (2009).

49. Zhang, Y. et al. Model-based analysis of ChIP-Seq (MACS). Genome Biol. 9, (2008).

50. Quinlan, A. R. \& Hall, I. M. BEDTools: a flexible suite of utilities for comparing genomic features. Bioinformatics 26, 841-842 (2010).

51. Althammer, S., González-Vallinas, J., Ballaré, C., Beato, M. \& Eyras, E. Pyicos: a versatile toolkit for the analysis of high-throughput sequencing data. Bioinformatics 27, 3333-3340 (2011).

52. R Core Team (2018). R: A language and environment for statistical computing. $R$ Foundation for Statistical Computing, Austria

53. Li, H. et al. The Sequence Alignment/Map format and SAMtools. Bioinformatics 25, 2078-2079 (2009).

54. Bray, N. L., Pimentel, H., Melsted, P. \& Pachter, L. Near-optimal probabilistic RNA-seq quantification. Nat. Biotechnol. 34, 525-527 (2016).

55. Robinson, M. D., McCarthy, D. J. \& Smyth, G. K. edgeR: a Bioconductor package for differential expression analysis of digital gene expression data. Bioinformatics 26, 139-140 (2010).

56. Ritchie, M. E. et al. limma powers differential expression analyses for RNA-sequencing and microarray studies. Nucleic Acids Res. 43, e47 (2015).

57. Liberzon, A. et al. The Molecular Signatures Database Hallmark Gene Set Collection. Cell Syst. 1, 417-425 (2015). 
bioRxiv preprint doi: https://doi.org/10.1101/2021.04 26.441414 this version posted April 27, 2021. The copyright holder for this preprint (which was not certified by peer review) is the author/funder, who has granted bioRxiv a license to display the preprint in perpetuity. It is made available under aCC-BY 4.0 International license.

A
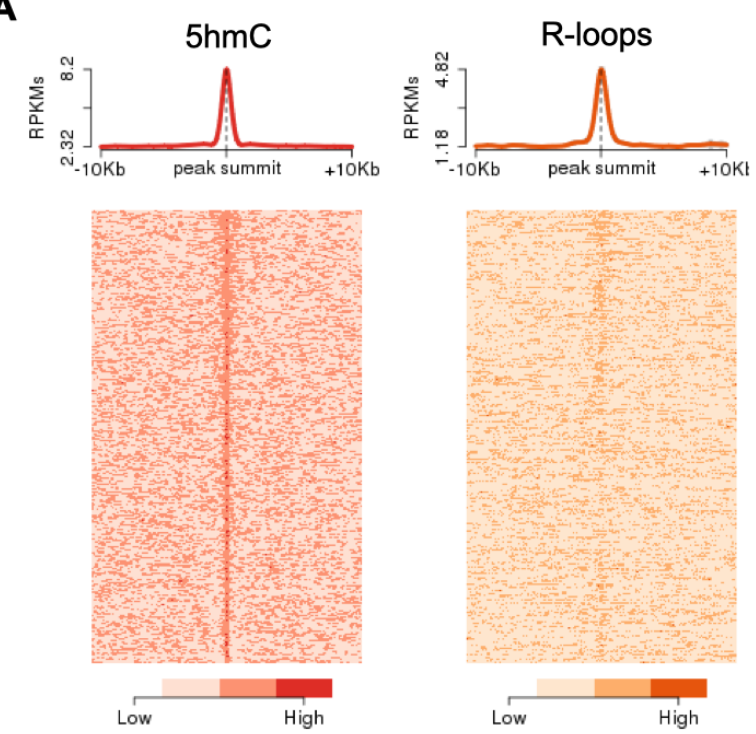

D
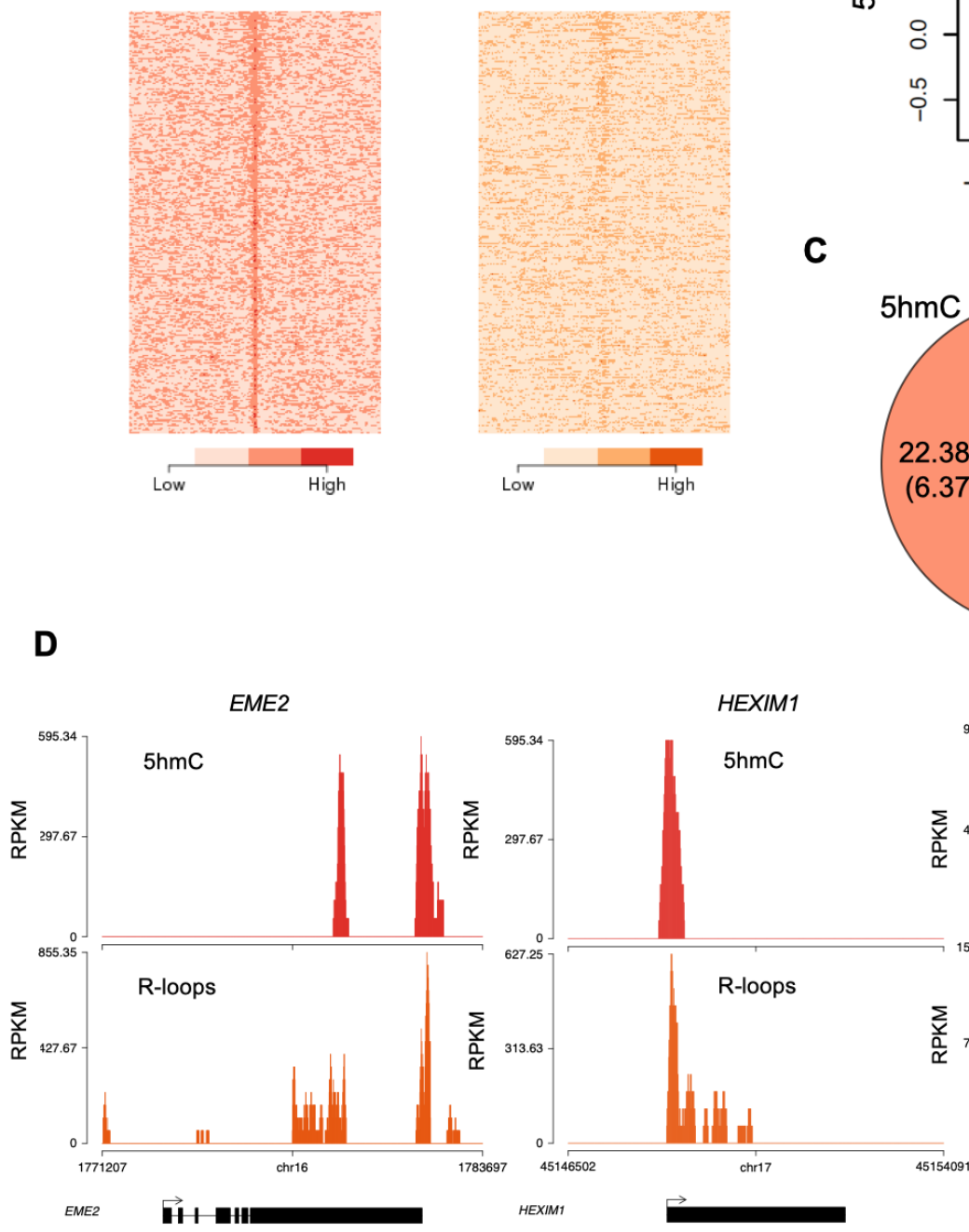

B

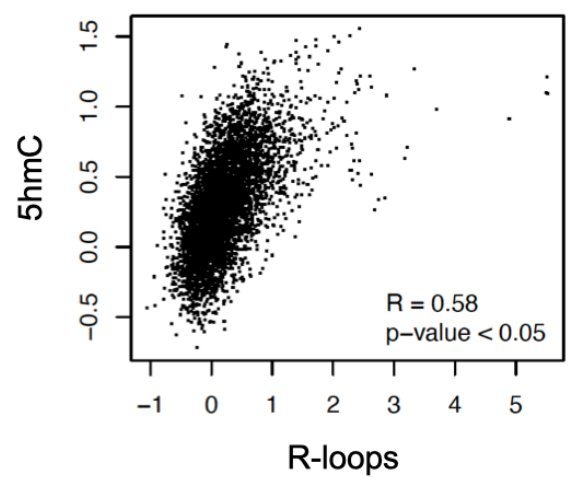

C

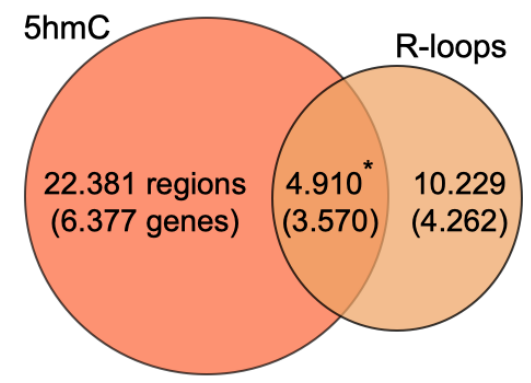

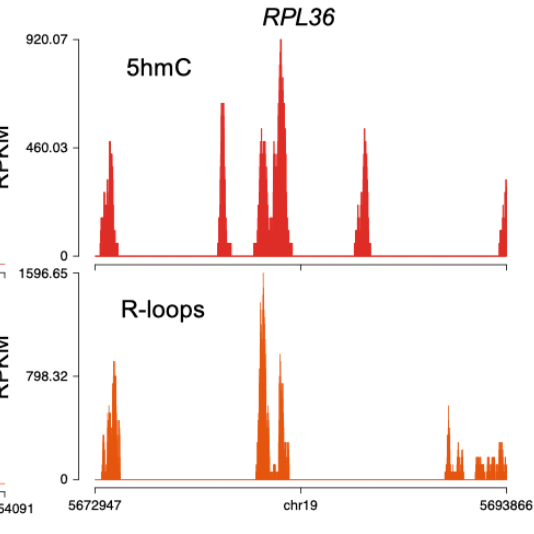

Supplementary Figure 1: Genome-wide analysis of 5hmC and R-loops in HEK293 cells. (A) Metagene and heatmap profiles of $5 \mathrm{hmC}$ and R-loops probed over fixed windows $\pm 10 \mathrm{kbp}$ around the $5 \mathrm{hmC}$ peaks in expressed genes. (B) Pearson correlation coefficient between $5 \mathrm{hmC}$ and R-loops distribution within active genes $(p<0.05)$. (C) Number of loci displaying $5 \mathrm{hmC}, \mathrm{R}$-loops, and overlapping $5 \mathrm{hmC}$ and R-loops. ${ }^{*}$ Permutation analysis, $\mathrm{p}<0.05$. (D) Individual profiles of $5 \mathrm{hmC}$ and R-loop distribution along the EME2, HEXIM1 and RPL36 genes. Density signals are represented as reads per kilobase (RPKMs). 
A

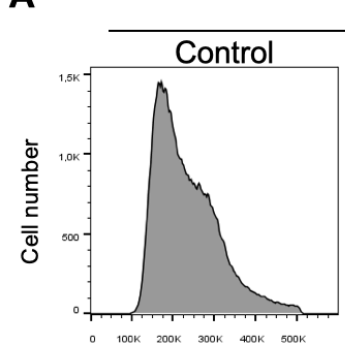

DNA content
$24 \mathrm{~h}$

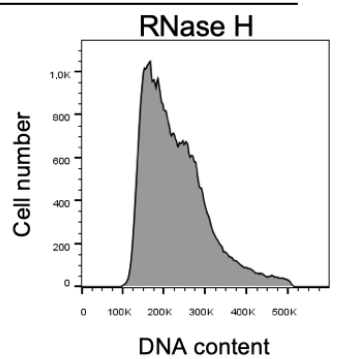

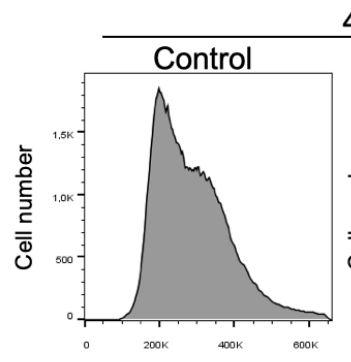

DNA content 48h $\quad$ RNase $\mathrm{H}$

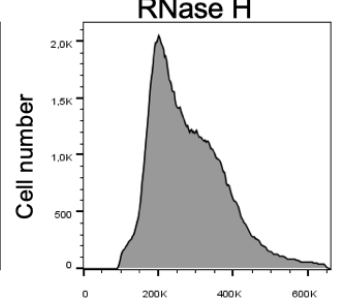

DNA content

B

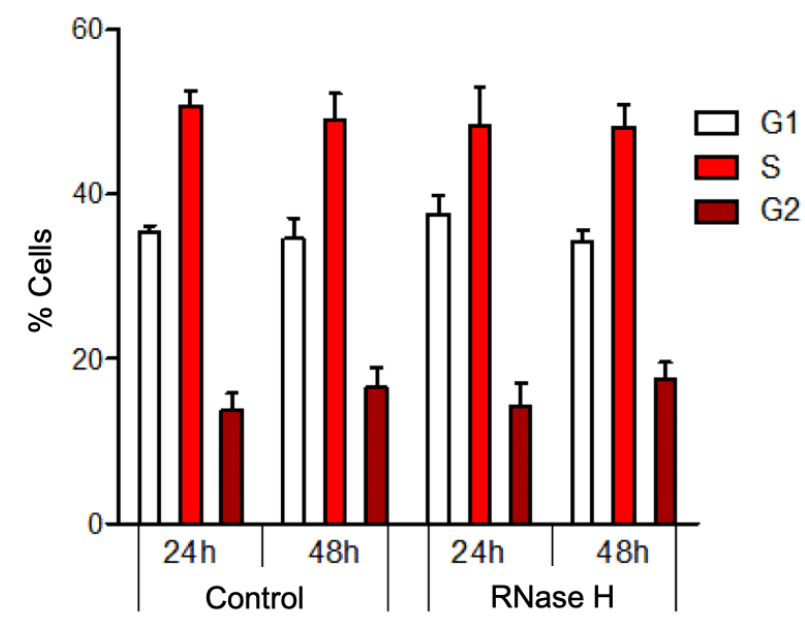

Supplementary Figure 2: Global R-loop suppression does not impact cell cycle progression of $\mathrm{mES}$ cells. (A) Flow cytometry analysis of propidium iodide-treated $\mathrm{mES}$ cells with ectopic expression of either GFP (control) or GFP-tagged RNase $\mathrm{H}$ for 24 or 48h. Data are representative of five independent experiments. (B) Percentage of control and RNase $\mathrm{H}-$ overexpressing $\mathrm{mES}$ cells at each cell cycle stage. Means and SDs are from five independent experiments.

Source data figure legends:

Figure 1 - source data 1. Original, uncropped images of all blots shown in Figure 1.

Figure 2 - source data 1. Original, uncropped images of all blots shown in Figure 2. 
763 Supplementary Table 1: Differentially expressed genes upon RNase H overexpression.

764 (attached Excel file)

765

766

767 Supplementary Table 2: shRNA sequences.

\begin{tabular}{ll}
\hline Gene knockdown & shRNA sequence \\
\hline Tet1 & $\begin{array}{l}\text { tgctgttgacagtgagcgcgctagctatagagtatagtaatagtgaagccacagatgtattactatactctatagct } \\
\text { agcttgcctactgcctcgga }\end{array}$ \\
Tet3 & $\begin{array}{l}\text { tgctgttgacagtgagcgcgcagtgtgtattcctaccattagtgaagccacagatgtaaatggtaggaatacaca } \\
\text { ctgcttgcctactgcctcgga }\end{array}$
\end{tabular}

768

769

770 Supplementary Table 3: Oligonucleotide sequences.

\begin{tabular}{ll}
\hline Primers & Sequence \\
\hline M13 FOR long & GTTTTCCCAGTCACGACGTTGT \\
\hline M13 REV long & AACAGCTATGACCATGATTACGCCA \\
\hline Tet1 Transcript FW & GAAGGTATCCCTCGCCTGAT \\
\hline Tet1 Transcript RV & CCACGAACAGCCAAAGGAGA \\
\hline Tet3 Transcript FW & ACACCCTCTACCAGGAGCTT \\
\hline Tet3 Transcript RV & GCAGCCGTTGAAGTACATGC \\
\hline APOE last exon FW & CCGTTCCTTCTCTCCCTCTT \\
\hline APOE last exon RV & TCCAGTTCCGATTTGTAGGC \\
\hline U6 snRNA FW & GCTTCGGCAGCACATATACTA \\
\hline U6 snRNA RV & AAATATGGAACGCTTCACGA \\
\hline Gapdh FW & AACTTTGGCATTGTGGAAGG \\
\hline Gapdh RV & ACACATTGGGGGTAGGAACA \\
\hline
\end{tabular}

771

772

773 
bioRxiv preprint doi: $\mathrm{https} \cdot / /$ doi org/10.1101/2021.04 26.441414 this version posted April 272021 . The copyright holder for this preprint (which was not certified by peer review) is the author/funder, who has granted bioRxiv a license to display the preprint in perpetuity. It is made available under aCC-BY 4.0 International license.

775 Supplementary Table 4: Antibodies used in this study.

\begin{tabular}{llll}
\hline Product & Concentrations & Company/ Cat. No. & Notes \\
\hline S9.6 & $5 u g /$ IP; $1: 1000$ (DB) & Millipore; MABE1095 & $\begin{array}{l}\text { Anti-DNA:RNA hybrid antibody used to } \\
\text { detect R-loops }\end{array}$ \\
dsDNA & $1: 1000$ (DB) & Santa Cruz; sc-58749 & $\begin{array}{l}\text { Anti-dsDNA specific antibody (HYB331- } \\
01)\end{array}$ \\
$5 \mathrm{hmC}$ & $5 \mathrm{ug} / \mathrm{IP} ; 1: 1000$ (DB) & Active Motif; 39791 & 5-hydroxymethylcytosine antibody \\
$5 \mathrm{mC}$ & $5 \mathrm{ug} / \mathrm{IP} ; 1: 500$ (DB) & Active Motif; 61255 & 5-methylcytosine antibody \\
\hline
\end{tabular}

776

778 Supplementary Table 5: g-blocks sequences.
g-blocks
B-actin P1
CTGACAACCGGTGTTTTCCCAGTCACGACGTTGTTAATACGACTCACTATAGGGTTACCCAGAGTGCAGGTGTGTGGAGA TCCCTCCTGCCTTGACATTGAGCAGCCTTAGAGGGTGGGGGAGGCTCAGGGGTCAGGTCTCTGTTCCTGCTTATTGGGGA GTTCCTGGCCTGGCCCTTCTATGTCTCCCCAGGTACCCCAGTTTTTCTGGGTTCACCCAGAGTGCAGATGCTTGAGGAGGT GGGAAGGGACTATTTGGGGGTGTCTGGCTCAGGTGCCATGCCTCACTGGGGCTGGTTGGCACCTGCATTTCCTGGGAGT GGGGCTGTCTCAGGGTAGCTGGGCACGGTGTTCCCTTGAGTGGGGGTGTAGTGGGTGTTCCTAGCTGCCACGCCTTTGCC TTCACCTATGGGATCGTGGCTGTCAGCCTTGAGGGTCAGCCTGGCCCAGGCTCCTGGCGTAATCATGGTCATAGCTGTTT GTACACTGACA

\begin{abstract}
B-actin P2
CTGACAACCGGTGTTTTCCCAGTCACGACGTTGTTAATACGACTCACTATAGGGGGGACTATTTGGGGGTGTCTGGCTCA GGTGCCATGCCTCACTGGGGCTGGTTGGCACCTGCATTTCCTGGGAGTGGGGCTGTCTCAGGGTAGCTGGGCACGGTGT TCCCTTGAGTGGGGGTGTAGTGGGTGTTCCTAGCTGCCACGCCTTTGCCTTCACCTATGGGATCGTGGCTGTCAGCCTTGA GGGTCAGCCTGGCCCAGGCTCCCATAGGCTTAGGAGAGGCCGCAATTCCTACCTGTTCATCCAGACAGAGGGGGACCTG GAATCAAAGTCAAGTTGGGGTAGGGGGTCCATGGGGCCATATCTGGCCTGCAGACAGCTCTGGTTAGCTATGGGCTGAG GTCTGGATTCTGCCTTGTGACTGGAGACTGGGCGCCATCCCGTGGCCTCTGAGGGCTGGCGTAATCATGGTCATAGCTGT TTGTACACTGACA
\end{abstract}

\begin{abstract}
APOE
CTGACAACCGGTGGTTTTCCCAGTCACGACGTTGTAATACGACTCACTATAGGGCCGGTGAGAAGCGCAGTCGGGGGCA CGGGGATGAGCTCAGGGGCCTCTAGAAAGAGCTGGGACCCTGGGAACCCCTGGCCTCCAGGTAGTCTCAGGAGAGCTAC TCGGGGTCGGGCTTGGGGAGAGGAGGAGCGGGGGTGAGGCAAGCAGCAGGGGACTGGACCTGGGAAGGGCTGGGCA GCAGAGACGACCCGACCCGCTAGAAGGTGGGGTGGGGAGAGCAGCTGGACTGGGATGTAAGCCATAGCAGGACTCCAC GAGTTGTCACTATCATTTATCGAGCACCTACTGGGTGTCCCCAGTGTCCTCAGATCTCCATAACTGGGGAGCCAGGGGCA GCGACACGGTAGCTAGCCGTCGATTGGAGAACTTTAAAATGAGGACTGAATTAGCTCATAAATGGCGTAATCATGGTCAT AGCTGTTTGTACACTGACA
\end{abstract}

